This article was downloaded by: [University of Glasgow] On: 22 December 2014, At: 01:02

Publisher: Routledge

Informa Ltd Registered in England and Wales Registered Number: 1072954 Registered office: Mortimer House, 37-41 Mortimer Street, London W1T 3J H, UK

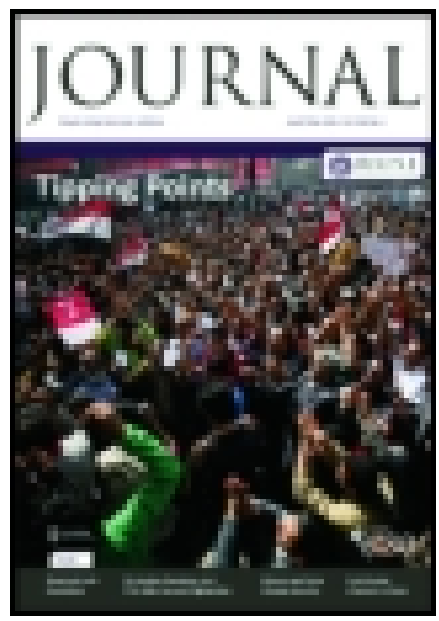

Royal United Services Institution. J ournal

Publication details, including instructions for authors and subscription information: http:// www. tandfonline.com/loi/ rusi19

\title{
On Storm Stability as Distinguished from Smooth-Water Stiffness
}

J ohn Scott Russell Esq. F.R.S., $\& c ., \& c$.

Published online: 12 Nov 2009.

To cite this article: J ohn Scott Russell Esq. F.R. S. , \&C. , \&C. (1879) On Storm Stability as Distinguished from Smooth-Water Stiffness, Royal United Services Institution. J ournal, 23:102, 821-860, DOI: 10.1080/03071847909441223

To link to this article: http://

dx. doi.org/ 10.1080/03071847909441223

\section{PLEASE SCROLL DOWN FOR ARTICLE}

Taylor \& Francis makes every effort to ensure the accuracy of all the information (the "Content") contained in the publications on our platform. However, Taylor \& Francis, our agents, and our licensors make no representations or 
warranties whatsoever as to the accuracy, completeness, or suitability for any purpose of the Content. Any opinions and views expressed in this publication are the opinions and views of the authors, and are not the views of or endorsed by Taylor \& Francis. The accuracy of the Content should not be relied upon and should be independently verified with primary sources of information. Taylor and Francis shall not be liable for any losses, actions, claims, proceedings, demands, costs, expenses, damages, and other liabilities whatsoever or howsoever caused arising directly or indirectly in connection with, in relation to or arising out of the use of the Content.

This article may be used for research, teaching, and private study purposes. Any substantial or systematic reproduction, redistribution, reselling, loan, sub-licensing, systematic supply, or distribution in any form to anyone is expressly forbidden. Terms $\&$ Conditions of access and use can be found at http://www.tandfonline.com/page/terms-andconditions 


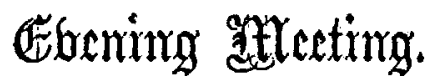

Monday, May 19, 1879.

AdyiRal Sir COOPER KEY, K.C.B., Member of Conncil, in the Chair.

\section{ON STORM STABILITY AS DISTINGUISHED FROM SIOOTH-IVATER STIFFNESS.}

By Johr Scotr Rosselr, EsQ., F.R.S., \&c., \&c.

I AM deeply sensible of the high honour you have done me in selecting me to prepare for you a statement and explanation, and practical applications of a portion of lydrodynamical science, of nautical experience, and of naval construction, which has not hitberto beon truly completely, or asefully treated either by philosophers or practical men.

The title you have given me for the paper has been most wisely chosen. It shows that experienced sailors know much better than landsmen what it is that constitutes a good sea-going, sea-keeping ship. It tells us that what the sailor wants for his ocean-loving home is not the fine-weather sacht, nor the smooth-water floating fortress built by modern landsmen, but the sea-going, sea-loving, ship-shape ocean man-of-war, which is always stable, quiet, gentle, easy, and graceful, whether in smooth ocean swoll, or in the storm of the hurricane, or on the breakers of the tempest.

Now I am quite willing and ready to fulfil the arduous dnty you have given me. I have devoted all my recent leisure to getting at the bottom of all the unsolved questions which it involves; but I am obliged to confess at once that $I$ cannot fulfil the whole of the task set me, in one sitting, in a manner worthy of the subject or worthy of the audience. I have, therefore, at once to beg you will excuse me if at the end of our meeting you find that I hare not exlinasted this prolific and useful subject, but only opened it up and covered a small part of a rery wide investigation.

In this difficult position I think I can be most useful if I first give you an inventory of the subjects to be considered, and of the elements of the questions to be asked and solved, and afterwards I may take up some of these questions and leave the rest till another time. 
Inventory.

1. What is a storm?

2. What is smooth water?

3. What is stifiness?

4. What is stability?

5. How is a storm created from smooth water?

6. How is smooth water got out of a storm?

7. How is a stable ship made?

8. How is a stiff ship made.

The answers to these questions open up quite another series. of questions which inevitably follow:-

9. What is the nature of sea waves?

10. What is the nature of breakers?

11. What is the nature of a ground swell ?

12. What are storm waves?

Afterwards follow these questions:-

13. How is a crank ship to be made stable?

14. How is a stiff uneasy ship to be made casy and stable?

15. How is a ship to be made stable in storm?

16.

17.

18.

19.

"

easy in tempest?

gontle on swell?

stiff under canras?

And at the same timesteady on wares?

20. Crankness,

21. Rolling,

22. Capsizing,

to be aroided.

\section{Part I.}

Now I will start at once with the fulfilment of my duty by taking up each of these questions.

I think that for your purpose it will bo most conrenient that I shonld begin at the end. I therefore at once take two forms of ship, both equally bad and of opposite badness, and ask you to choose the better from the worse as our first step in progress. (See Figs. 1, 2, 3.)

Fia. 2.

Fro. 1.

Fra. 3.

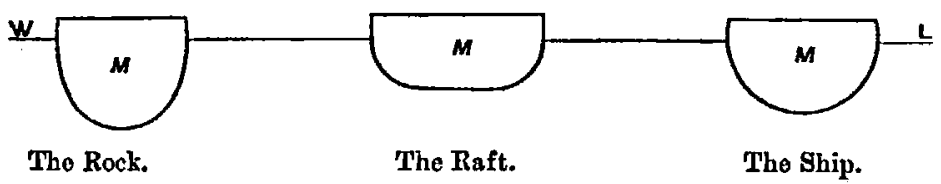

The ship-shape is easy, lively, stable, and gentle.

The raft is lively and stable in smooth water and fine weather only.

The rock is steady and stablo in all weather, never easy, gentle, nor lively, always quarrelling with the wares until beaten in or broken up. 
Let us now study the behaviour of each of these ships on the waves, and the causes of that behaviour.

1. The shoulders of the raft are too broad and too strong. They. are so powerful and so large, that smooth-water waves and small sens have not size nor power to move them fast or far, and therefore move them slow and gently.

But these brond shoulders are just the lerers which the storm wares use to jerk the raft up and down with quick, riolent motion, and they furnish the powerfal lever by which the destroying waves called wreckers or breakers get hold of the ship, mount upon the deck, and overwhelm it.

Thus the shoulders which give smooth-water stability, give violent motions and dangerous positions under the attacks of storm waves.

2. The rock, on the contrary, is stiff and upright in smooth water, and carries great press of sail with small inclination. But it stands too upright and too stable when among the storm wares, for the wavemotions are both horizontal as well as vertical, and the violent horizontal motions of storm waves in the cross sca, first deal violent blows on one side and then on the other, to which this rock does not yield, and this riolent collision first straing the ship, next takes the sea on and over her, and at last injures her structure, and may break her up in the end, and send her down.

3. Is there a middle form between these two which possesses the good qualities of both without the faults of either?

To discover this form is the problem jou have set me. This problem I have undertaken, but I do so with a deep sense of its difficulty, botb as to the perfectly precise, true, and exact solution of the problem, and especially as to my ability to make so deep and complex a question a matter of verbal explanation. But I have one comfort, I am glad it is you, the practical and experienced men of the sea, who have asked me for this explanation; that tells me that you feel it to be a grent want, and your asking me makes the solution of it a great duty, which I now feel bound to fulfil as best I may.

The problem las two parts:- -

The nature of the stormy sea.

The nature of the seaworthy ship.

Whence the trro questions-

I. How is the water behaving on the ocean when gentle winds make gentle waves, and how, otherwise, in storms and amid breaking waves?

II. How should a ship be built so as to behare well and keep gentle and quiet equally amid ocean wares in fine weather and ocean wares in tempest, tumult, and storm?

I. The behaviour of water in wind and storm is generally eapressed by the words-maves, swell, and breakers.

We may, therefore, first take smooth water, and ask how it becomes troubled and stormy? To discover the answer to this question I had to devote ten jears of continuous obserration to the study of waves and water-motion, and to exact experiment and observation upon them. I will endeavour to give yon the results in few words. 
I fonnd there were four kinds of water waves, all quite different in nature. The skin ware, the surface ware, the ground swell, the unseen wave.

1. The Stizin Ware.-If you look at $a$ smooth sea on a still day, you will see here and there gentle wrinkles on the face of the water; they may be long though small and narrow-mostly quarter of an inch to two inches bróad-like threads or ribbons skimming along the smooth, shining, mirror-faced water. Theso are caused by gentle airs in still water, and also by nnder-water currents in disturbed water. You can make them by moving a slender thread or line along the water, as in fly-fishing, or by cutting the skin with a penknife as you row'gently along smooth water.

I found that these beantiful little wares were the consequence of a strange fact then unknown. The surface of the water where it meets the air is parted off from abore and from bolow by a solid, strong, tough skin, quite unlike the water below: it is hard, unyielding, and solid, like ice. If ice were tongh and would bend easily, I should call this skin "ice;" but ice cracks when you bend it. This is so tough that it bends casils; you can cut it with a knife, but it requires a pressure of about half an ounce to an inch to cut or split it, or $4 \frac{1}{2}$ lbs. to the foot is the limit of its toughness; it is like leather rathor than ice. In bright sunshino in a clear stream you can see it play all sorts of tricks, and you can see the wind and the fish and flies playing all sorts of tricks with it. The skin waves cover the surface with wrinkles on the first approach of the wind.

2. The Surface Waves.-The first symptom of coming wind in smooth still water is a series of long lines of skin warcs, each not more than 2 inches broad. As the wind adrances it soon makes itself felt by heaping up the wrinkles of the skin waves into piles and rows and ridges, growing from 3 and 4 inches wide and $\frac{1}{2}$ an inch high, gradually on to 3 and 4 feet ride and $\frac{1}{2}$ a foot high.

The standard ware, by which I mensure and compare the times and speeds of all other surface water wares, is as established by mj original observations, 1834-1844.

\section{Fig. 4.}

Standard Surface Ware.

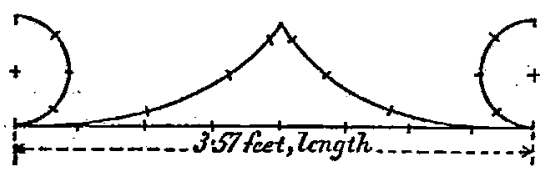

One second time. Speed 357 feet". Limiting leight one foot.

The $\{3 \cdot 57$ feet long, from crest to crest.

Standard $\left\{\begin{array}{l}3.57 \text { feet por second, speed of travel. } \\ 1 \text { second of time-duration. }\end{array}\right.$

The model wave, by which I measure the form and calculate the phases 
- Tournal RUS. Institution.

vole3.

P1XXXV

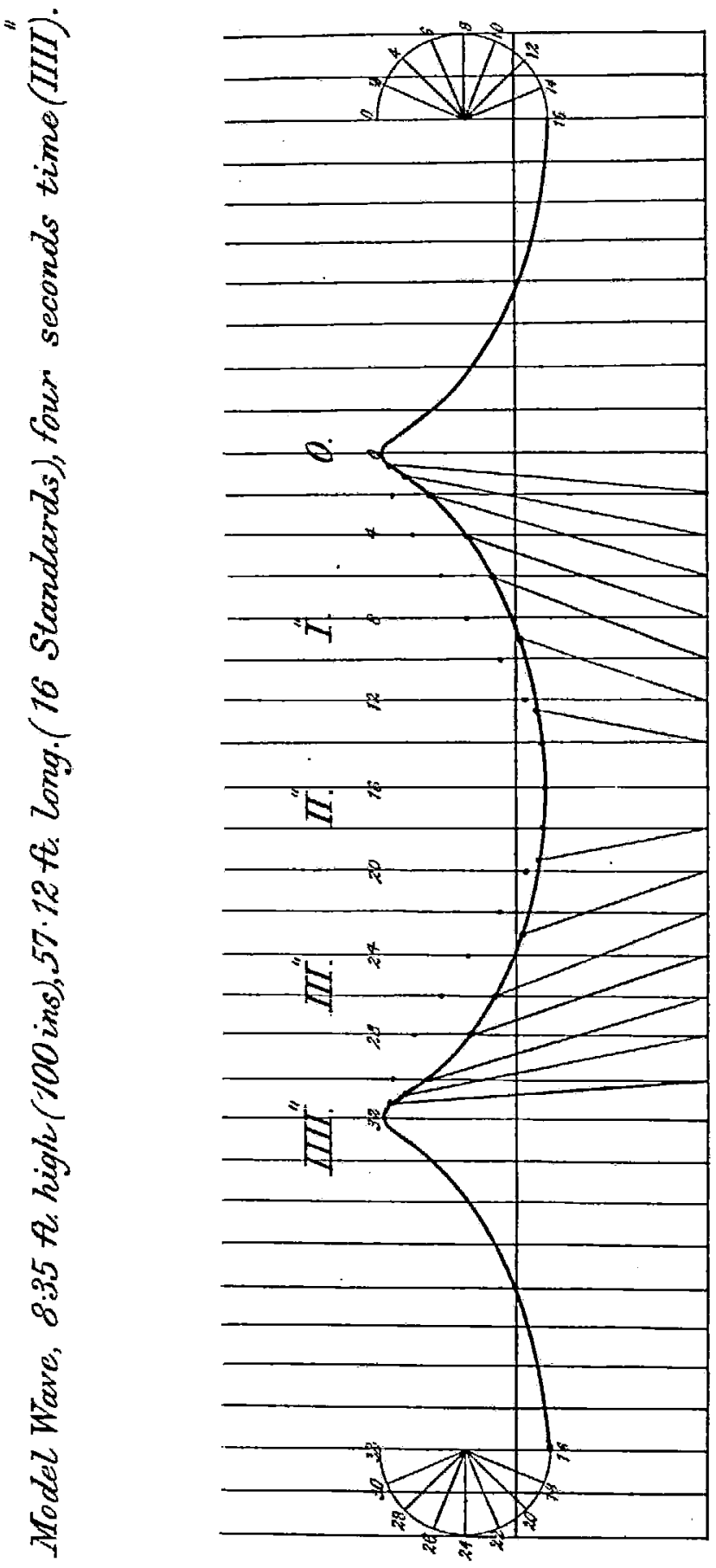

 
and heights and rise and fall of waves is as shown in the large Diagram. (Plate XXXV.)

$$
\text { The }\left\{\begin{array}{l}
8 \cdot 33 \text { feet high. } \\
57 \cdot 12 \text { fect long. } \\
\text { Wodel } \\
\text { Ware. } \\
4 \text { seconds of time - duration. }
\end{array}\right.
$$

All other waves of this order may be thes calculated by the standard.

TABLe I.

Table of Surface-Sea Waves. Calculated by the Standard.

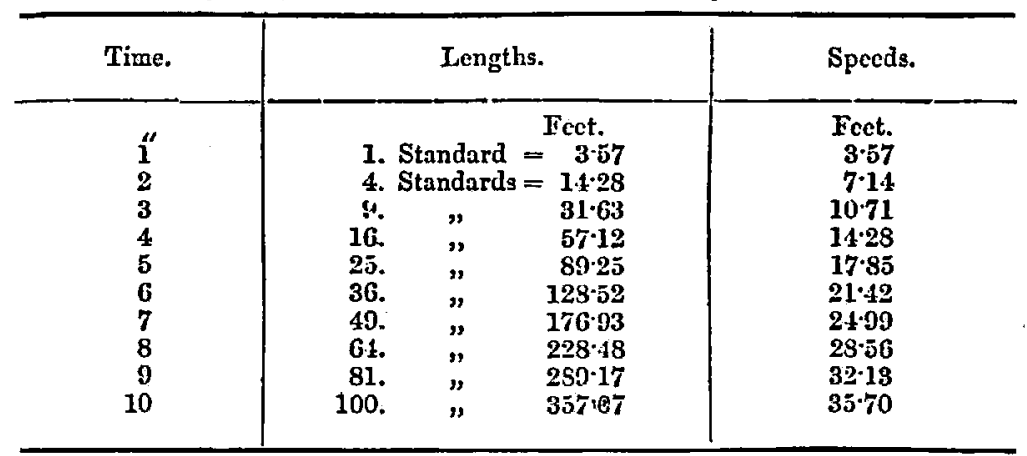

Heights of surfaco waves are not inserted in the table for important reasons.

The chicf reason is isochronism. It may scem strange, bat it is exactly true, that a ware of given length and given time inay vary in height from highest to lowest, and yet never take longer or shorter time to go throngh its changes of form or changes of place.

But there is an extreme or limaiting height to each wave. This may be called the breaking height. For the standard wave it is one foot.

All wares of the lower heights behave in similar ways, and leep time with each other and with the normal or ruling ware.

But whenever circumstances, either under water or above water, sach as wind and storen, or rock or ship, or one wave interfering with another wave, tend to push the wave ligher up than this normal height, order and time-keeping may be destrojed. The ware then brenks, its parts are separated, and they spread abroad.

When a wave breaks, order and time-keeping are destroyed, rule ceases to be abejed; the particles of water go each one its own way; the union under rule and order which constitutes a wave-community ends; the drops of water going each its own way-it becomes chaos, anarchy, disorder, ruin; the wave broken up disappears for ever; the dead water exists, the living wave is gone!

How and why all this takes place and ends in ware destraction, and often in shipwreck, I cannot explain until 1 hare gone further and deeper into the question, and sliown you what is the rule and order which governs each individual waler-drop, under the surface, and the sum total of which make up the wave-mass. 
3. Under-Water Wave-Ilotion.-The waves which we seo on the surface of the sea have forms of benuty, which this dingram shows; and graceful motions, which this diagram measures; and their dances keep time, which this time-table tells; but all we see on the surface is semblance rather than trath.

What is happening under the water-level is quite different from what is seeming to happen on the water-face.

On the water-face, the wave seems to glide slowly or rush rapidly along one way; say, from the left on towards the right. Our model ware, with a ranning speed of near 10 miles an hour, rushes past with an impnlse which, if it were real, would crush in the side of a powerful ship. But it does not crush or injure it. The water nnder the surface does not go past with the ware 10 miles an hour. It merely swings gently fore and aft, swells gently up and down, and remains in much the same place where tho wave found it before it passed.

The under-water motions of sea waves are most instructive, and are the essence of our present study. To know what they are we must have spent years, as $I$ had to do, in looking and searching, in shallow water and in deep water, to find out what each little round globe or drop of water in the deep sea is doing while the waves are dancing above their heads.

The result is what I have now to tell you, that each little atom of water is revolving, in a circular path, in the same regular way in which the moon goes round the earth.

During a long wave, each drop of water makes a slow revolution in the same time in which the wave travels its own length; and daring a short wave it makes a quick revolution in the shorter time of the wave transit. Under a high ware each drop of water revolves in a larger circle, and under a low wave in a less circle, but always by law and order, just as a planet round the sun. It is the study of these laws, and the knowledge of these facts, that must teach us the nature of our ocean waves, and how we have to deal with them.

A first principle in water ware-motion is, that "the sea is full," This is littlo or ill understood. Even "great authorities" are misled and mislead others by neglecting this. They talk and teach about water and water lines and water streams as if thes were plastic, accommodating, retiring soft groups, that were ready to take any shapes and make room for any other shapes and bulks, and gire place to the intrusion of any other sort of bods, if not too large and bulky to find room for.

On the contrary, pray remember that "the sea is fall," and that there is no room uuder the surface for anything more than is there already; that is the first principle of complete wave-knowledge.

The first consequence of this principle is, that you cannot make room for a ship or for a mass of water, under the surface of the still water, except by lifting an equal mass out of the water, and setting it up above the water-level. One can only enter in by turning another one oat. Place nust first be found for one to be turned ont of before another is turned in.

When a ship is launched from the slip on to the open water, an amount of water equal to her own weight, and equal in bulk to her 
room in the water, is removed from below, and is absolutely laid in a leap on the top. The same is trae of the water in a ship's way when she mores. Erery atom of water in her way must have room for it found above the water-level. If the water be shallow and narrow, the water heaps up so high that it overflows all its bounds. If the water is wide and deep, the heaped ap water on the top is spread out farther, faster, and wider, and in the deep sea tho displaced mass spreads ont so fast and far and wide as to fill up so low a place in so thin a layer as to be scarcely visible, and this is the reason why this now settled fact was so long unknown, and may still be misunderstood or mis-stated. All the water removed out of the way of a sailing or steam ship must find room on the top of the sea, for there is no room left below.

A second question rises here. That will happen to a still, full sea, if, by any huge force, a mass of water were lifted off out from its level face? The first answer is, that some of the water below would spring right up into the hollow. The next answer is, that some of the water left around would tumble into the hollow. That is true, but more must follow. That is not enough to fill the roid.

To fill up the void, some other void must be made elsewhere! The water cannot rest around a hollow till water has been fetched from some other place, far or near, to fill up the roid; so, where a roid is made, we must seek far and wide for means to fill that void.

Now, we have two results of any action on the face of still water. 1. A heap of water added cannot stay, it must go away and find a now placo elsewhere. 2. A hollow scooped ont of the water level cannot remain there; enough water to fill in must be sent there from elsewhere.

A water ware is merely an engine or mechanism or apparatus for doing this work of restoring the disturbed water-level. It does its work admirably, and we hare now to see how the storm stirred ap by wind is ondone and set right again by the waves after the storm goes past.

I begin with a hollow scooped out from the surface of still water. This hollow is filled from opposite sides, by waters falling contrary

Fia. 6.

Surface water scooped out.

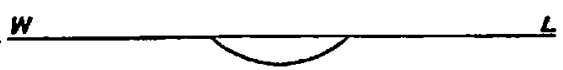

FIC. 7.

Falling in. Filling up. Falling in.

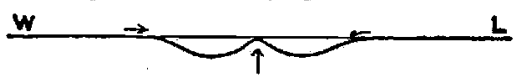

Fra. 8.

Falling in. Full swing upwards. Falling in.

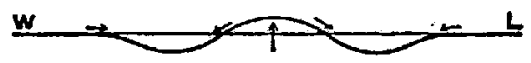


Fra. 9.

Oscillating.

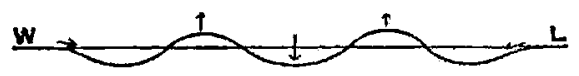

Fir. 10.

Oscillating and spreading out.

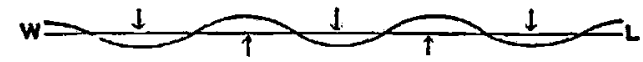

wajs. These opposite waters meet, strike, rise up, and form a central heap. This heap falls, fills the hollows it had left on either side, and they, thus filled, also heap up in pairs. Two more heaps fall in on two sides, leare two more hollows, which are, in turn, filled by meeting and clashing heaps. Thus there comes the odd numbers of three wares, firo waves, and seren waves, so well-known to sailors as the groups of the sea. There is the one central largest wave, then two smaller ones on each side, sometimes accompanicd with more smaller still, making five, or cven two more, equal seven. (See Figs. 6, 7, $8,9,10$.

4. Forces and Speeds of Water in Waves.-Happily for us there are one or two simple principles of universal motion, expressed in formal laws by Sir Isaac Newton, which enable us to measure water motions just as he measured planet motions. His law of the apple falling from the trec is all we want, only he did not tell us how, after the apple fell from the tree, it was to get up there again, and that is what we hare to settle. We readily see how the apple falls, but even Sir Isaac Newton did not accurately show how to get it up again.

- Hydrodynamic science or water motion has this great aim-to settle the relations of height, depth, speed; time, and force.

The first law is called the law of height due to speed, and speed due to height. The law is as follows:-

The fall of a drop of water through 1 foot of height is done in a quarter second of time. The speed produced in the wator by this foot-fall is 8 feet a second, or over 5 miles an hour.

The fall of a drop of water through 4 teet of height is done in half-a-second of time. The speed produced in the water by this fall is 16 feet a second, or over 10 miles an hour.

The knowledge of this simple fact enables us at once to settle the following points :

$\dot{A}$ surface wave a foot high above the level, if falling free would take one-quarter of a second to fall, another quarter to get up again. Also, if it had to go down into a hollow of a foot deep, and to come up again, it would take two quarters more. Thus a wave n foot high with an equal hollow might be expected to accomplish its work in four quarters of a second. This is what it does in our standard wave, with some modification in manner.

The modification in manner of fall by ware-motion is what is called the principle of isochronism. . Our standard ware has the remarkable quality, that whether it falls from' 1 inch high, or from 2 inches high, 
or from 10 inches high, it occupies just the same time, viz., 1 second to complete the waye.

The principle of isochronism is this-that if you confine a force and apply it in such manner that you can vary it just in the proportion of the work to be done, you will do the more work in the same timo as the less work.

Now this nature wanted is the exact nature of a water column.

Take a water column, say in a glass tube, with its lower end in the water and its upper end open, now close the tube with your finger and raise up a column of water, say a foot high above the level, then open the top of the tabe and let the water column descend, and mark what time it takes; next raise only 6 inches, keeping overjthing else alike, and the descent through 6 inches will take the sane time as through the foot.

The reason is this--the tall water column had twice as far to go, and twice the work to do, but it was twice as strong from its double height, and so did the donble work in the same time. Wavo heights are water colnmns-before they get down to or below the level, they must more the water under them out of thcir way-that is their work. When twice as high they do twice the work, and do it in the same time, all else being equal.

The next law I will call the law of equality all round, or if gon like Greek words better than English, I will call it hydrodynamic homology.

I mean that this speed due to height in hydrodynamics, applies equally to water motion in all directions. Thus in the hollow of a wnve, the water below the level pushes apwards as fast and as far as the water above the level pushes downwards, and does its work in the same time.

I next mean, that under a wave or water column a foot high, the water will go forward with the speed dno to the height, just as well as upwards; and backwards just as much as downwards.

Without going into further detail I merely wish you to notice, that with these units in soar mind, of 1 foot high, one-quarter second time, and 8 feet a second of speed, you can always measure what a mass of water is doing when it drives another of its own size anywhere anyhow.

Now surface waves are merely masses of water displacing one another successively, in place and out of place, by these few simple laws-of due height, due depth, and due speed-moving and keeping. time in isochronic columns, and distributing moving force equally np and down, to and fro, in settled direction determined by the moving cause.

I took the scooped-out wave first, because that is the typo of what I call the oscillating wave. The heaped-up wave is quite of another type, which I call the travelling wave or wave of translation, or, as it is sometimes called, the carrier wave, or the solitary wave. A high heap of water, let into or set up upon the top of still deep water, does not create a family group of waves. It remains a single solitary wave; it has no oscillating or backward and forward motion; its 
motion is all one way. It is the nature of wave to which we give the name of "swell." It is much longer and faster than the surface waves, and its action goes deep down into the water, and reaches to the bottom, while tho action of the other waves stays near the surface. Hence we call it "ground strell."

Now both these classes of wares, the wind waves and the ground swells, perform this function, they restore the equilibrium of the water. The hollow made by the scooping action of the wind is spread ont in a thin layer, all over the top of the water, as far as the wave can reach; while the heap raised up by the wind is also rolled out into a thin film and spread all over the top of the water. But the solitary wave or ground swell performs a very different function. It carries off the heaped-np water to far off seas and shores, and spreads it all over the sands and shallows, where it expends its force in heaving up sands and rolling up pebbles and turning into fragments the rocks on the bottom of the shores of the sea.

The effects which these motions under the surface and on the surface produce on the ship, which is afloat upon and within the body of these waves, is what we must now seek.

What we have chiefly to kecp in mind is that on or near the wave. crest the water in the ware is flowing forwards; that in and near the wave-hollow the water is flowing backwards; that in and near the middle of the wave-front the water is flowing upwards; that in and near the middle of the ware-back the water is flowing downwards'. (See Figs. 11, 12, 13.)

\section{Frg. 11.}

Surface Ware. Breaking IIeight.

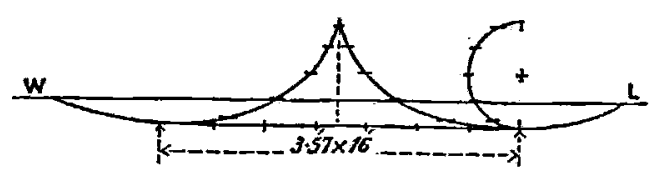

Fra. 12.

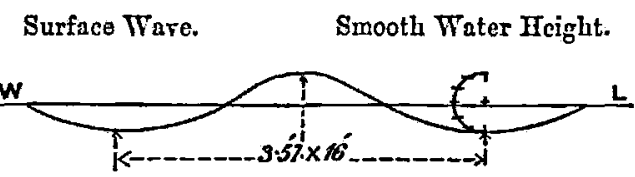

Fra. 13.

Surface Ware. Subsiding to Ground-Swell.

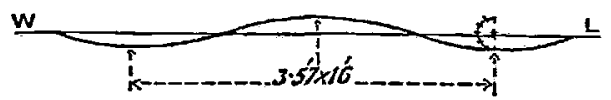

We hare next to bear in mind that a water-borne ship will rest on the summits of these water-columns. 
FIG. 14.

Pair of Hollows. Pair of Hans.

Eements.

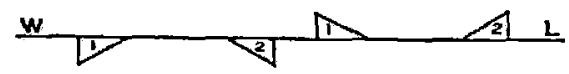

FIO. 15.

Placed.

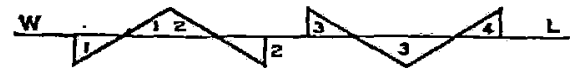

Fig. 16 .

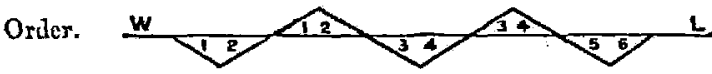

Fid. 17.

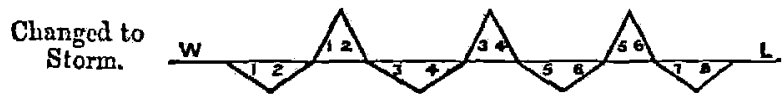

Water Motions in Waves along the Civcular Paths of Water Particles.

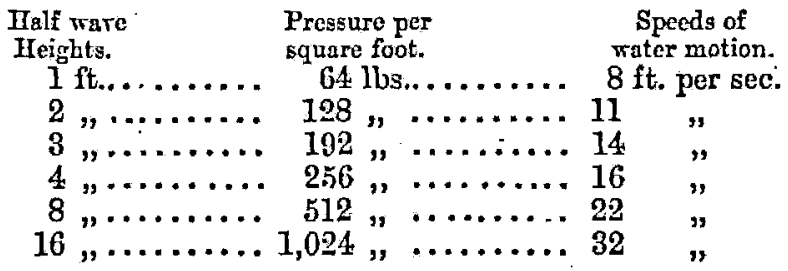

Thus, therefore, the waves which cover the surface of the sen are masses which seem to fly hither and thither, and keep exact time, and seem to flow on with high speed. But this is an appearance only; the reality is that the masses of water remain in the same places or change only through a small range, while the wares in shape seem to fly afar. In each portion of one wave the water-particles are going each around in its own circle with a nniform known speed. Through one quarter of its cycle it goes npwards, through the next quarter forwards, through the third quarter downwards, and through the last quarter backwards to its old starting-point. Then begins a new cycle of the next wave.

These phases deserve careful study on the large diagram. (Plate $\mathrm{XXXV.)}$

It is to these wave-motions of the water particles that we must pay careful attention if we are to create ships which shall suit the motions of the waves, and which shall neither disturb the motions of the wares needlessly, nor be thomselves needlessly disturbed by them. 
Monday Erening, June 9.

VICE-Adiriral E. GARDINER FISHBOURNE, C.B., Vice-President, in the Chair.

\section{PART II.}

At our former meeting I limited myself to the investigation of the origin, nature, and effects of what I called surface-sea waves, as these are the most common and most visible on the ocean in storms. I will now proceed to the examination of another class of waves, quite different in nature and effects from surface-sea waves; although both may equally have their origin and do their work in one and the samo storm.

The other class of waves may have sereral names-

Waves of the deep.

Ground swell.

Rollers and breakers.

Earthquake waves.

Tidal wares.

Cyclone wares.

It is essential to understanding this class of wares to make it clear in our minds that the two classes are quite different in all their phenomena, although the sume laws of hydrodynamics goveru both, and they may often have, or seem to have, the same origin. Each explains the other not as its like, but as its contrary.

As wo have already seen, surface waves may appear in groups-a central one, two side ones, two more, and two more, diminishing outwards. (See Figs. 6, 7, 8,9.) They may also havo one leader and Fra. 6.

Surfice water scooped out.

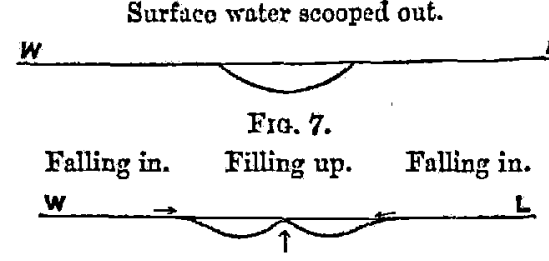

EIC. 8.

Falling in. Full swing upwards. Falling in.

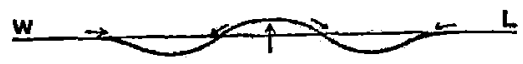

Fia. 9.

Oscillating.

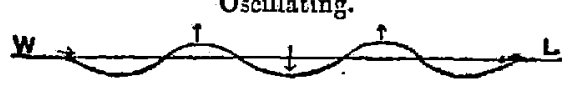


Fra. 10.

Oscillating and spreading out.

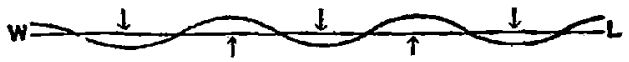

a following. (See Fig. 10.) But I have now to introduce to your notice a ware of the deep, with no leader and no follower. Henco he is sometimes called the solitary wave. This ware of the deep

Standard Deep Water Warc.

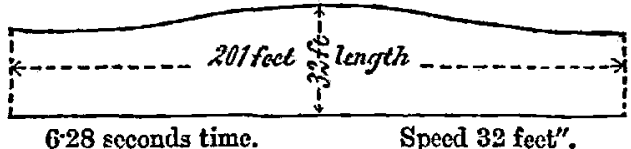

Limiting ware height $=$ Still water depth.

Height of ware-crest abore water bottom, 32 feet.

FIG. 21.

Shape of Ground Ware.

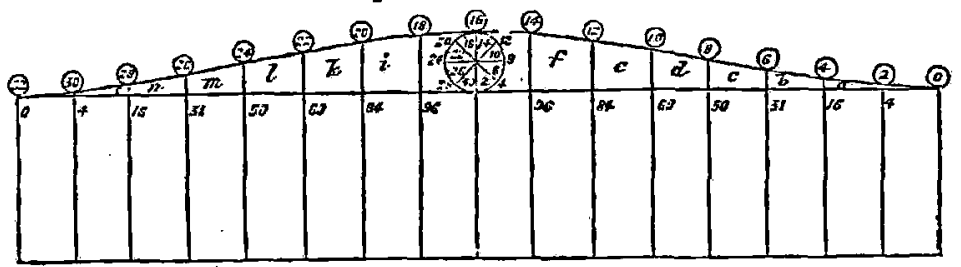

Fig. 22.

Water Columns in

Ground Ware.

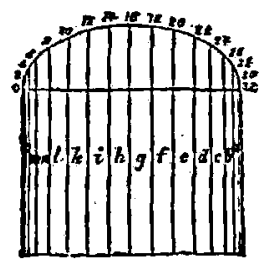

FrG. 23.

Water Mass mored during Ware Transit.

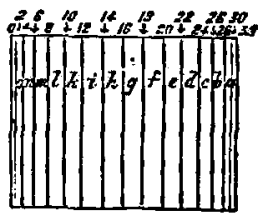

travels with great speed, from 10 miles an hour in water 8 feet deep to 600 miles an hour in ocean depths. (Seo Figs. 5, 21, 22, 23.)

This ware of the deep carries any force committed to it to any distance in short time, and delivers it up at that distanco entire, with only tho percentage due to imperfect fluidity of water. Hence I havo sometimes called this " the carrier wave."

This wave leaves no hollow, has no follower; it finds the water still and leaves it still; it does not repeat itself. This wave lifts every particle of the decp beneath it a little npward, carries it a good deal forward, then lays it gently down again to rest, but in a new place; and it does this to every particle of the deepest water over which it passes. Hence from this power of water-moving I have called it "the 
"ware of translation." Because it docs its work right down to the bottom, it is also called "the ground swell."

This wavo as a carrier will take the forces of a storm or a hurricane from any part of the sea with a speed much grenter than the storm itself, and will deliver them on a distant sea-shore long before the storm itself reaches that shore.

The following is a table of the speeds with which a wave of the deep will carry its force and do its work afar orer the ocean.

Table of Deep-Sea Wares.

\begin{tabular}{|c|c|c|c|c|}
\hline \multicolumn{3}{|c|}{$\begin{array}{l}\text { Deep sea. } \\
8 \text { ft. deep. }\end{array}$} & \multicolumn{2}{|c|}{$\begin{array}{l}\text { Carrier specd. } \\
10 \text { miles an hour. }\end{array}$} \\
\hline 32 & " & $\cdots \ldots \ldots \ldots \ldots \ldots$ & 20 & , \\
\hline 128 & $"$ & $\ldots \ldots \ldots \ldots \ldots$ & 40 & $"$ \\
\hline 512 & ", & $\ldots \ldots \ldots \ldots \ldots \ldots$ & 80 & "צ \\
\hline 2,048 & " & $\ldots \ldots \ldots \ldots \ldots$ & 160 & , \\
\hline 192 & " & $\cdots \ldots \ldots \ldots \ldots$ & 320 & , \\
\hline 32,768 & $"$ & $\ldots \ldots \ldots \ldots \ldots \ldots$ & 640 & $"$ \\
\hline
\end{tabular}

If an earthquake sent up its force from the bottom of the sea in a great wave to the top, and the depth of the sea were 100 fathoms, this water-ware would carry the effect along the deep at over 80 miles an hour and would deliver the equivalent mass of displaced water in a destructive flood over a shore 1,000 miles off twelro hours afterwards.

\section{Transformation of TWaves.}

Model Surface-Sea Wave transformed into Mrodel Deep-Sea Wave.

Horr a surface wave, created by the force of the storm, is to be trans. formed into a ground swell, and so carried away to a distance, remains now to be examined.

Let us select for our first experiment the model sea-wave already giren in our table.

$$
\begin{aligned}
& \text { Model Waves. }
\end{aligned}
$$

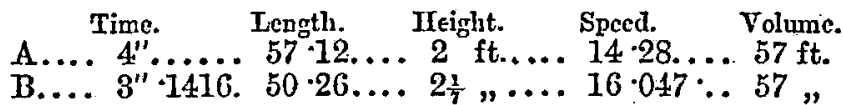

$A$ is the sea-surface ware; $B$ is the deep-sea ware nearest to it. The two are of nearly equal volume. $B$ is the faster and the higher and the shorter.

What is necessary to transform this surface ware into this ground swell is this inevitable condition, "that the water shall shoal up from " the bottom to less than eight feet deep."

When this happens, what was a negative ware will hare its hollow below the surface filled up by the uprard pressure of the rising bottom. It will cease to be hollow. It will have become a ground swell, and have all the characters of a mave of translation. It will have the same moving mass as before, and be slightly faster. But its speed will thereafter increase and diminish with the change of depth.

From our tablo of surface wares, let us take another longer and faster warc. 


\section{Another Wave, transformed.}

$\begin{array}{ccccc}\text { Time. } & \text { Length. } & \text { Height. } & \text { Speed. } & \text { Tolume. } \\ \text { C 9" } & 289 \text { feet } & 8 \text { feet } & 32 \text { feet } & 1,156 \text { feet. } \\ \text { D 6".28 } & 201, " & 12, " & 32 " & 1,206 "\end{array}$

$\mathrm{C}$ is the surface-sea wave taken from tho table. $\mathrm{D}$ is the nearest deep-sea ware of like speed.

201 feet is the ware.length duo to that time in 32 feet depth of water, and 32 feet is tho depth of water for the ware of 32 feet speed, The resnlting wares are nearly equiralent.

The result of this transformation will be that the swell ware will retrrd its motion in 18 feet deep to 24 feet speed, and will accelerate its motion in 50 feet of water to 40 feet speed: That, in the shallower water, its height will rapidly increase, and in the deeper water will rapidly diminish, while the wave-Iength will diminish and increase in converse proportion. One Solitary Deep-Sea Ware.

\begin{tabular}{|c|c|c|c|}
\hline $\begin{array}{l}\text { Time. } \\
20^{\prime \prime} \cdot 42\end{array}$ & $\begin{array}{c}\text { I.cngth. } \\
2,122 \text { fect }\end{array}$ & $\begin{array}{c}\text { Specd. } \\
104 \text { feet }\end{array}$ & $\begin{array}{c}\text { Decp. } \\
338 \text { feet }\end{array}$ \\
\hline
\end{tabular}

Tolume. Translation mass. Tons. 32,260 fect. 96 fect 924 tons.

This solitary deep-sea wave is an example of the important influcnco of depth of water, on the speed and length and mass of a ware. $A$ surface-rrave of $20^{\prime \prime}$ time would be only 1,428 feet long; this is 2,122 feet long. The speed of the surface wave is only 71.4 feet a second, and of the deep ware is 104 fect a sccond. Tho wares, if of like height, would differ in mass nearly as 2 to 3 .

Table II.

Table of Deep-Sea Wares or Ground Swell. Calculated on 32 feet as Standard.

\begin{tabular}{|c|c|c|c|}
\hline Sea depths. & Ware-lengths. & Ware-time. & Transmission speed. \\
\hline $\begin{array}{c}\text { Feet. } \\
\mathbf{3 2} \\
\mathbf{5 0} \\
72 \\
\mathbf{9 8} \\
\mathbf{1 2 3} \\
\mathbf{1 6 2} \\
200 \\
288 \\
\mathbf{3 3 8} \\
\mathbf{4 5 0} \\
\mathbf{5 1 2} \\
\mathbf{6 1 8} \\
\mathbf{7 2 2} \\
\mathbf{8 0 0}\end{array}$ & $\begin{array}{r}\text { Fcet. } \\
201 \\
314 \\
452 \\
614 \\
804 \\
1,016 \\
1,956 \\
1,808 \\
2,122 \\
2,826 \\
3,216 \\
4,076 \\
4,536 \\
5,026\end{array}$ & $\begin{array}{r}6 " .95 \\
7 \cdot 85 \\
9 \cdot 49 \\
10 \cdot 99 \\
12 \cdot 56 \\
1 \cdot 1 \cdot 15 \\
15 \cdot 70 \\
18 \cdot 81 \\
20 \cdot 19 \\
23 \cdot 45 \\
25 \cdot 12 \\
28 \cdot 31 \\
29 \cdot 84 \\
31 \cdot 41\end{array}$ & $\begin{array}{c}\text { Fect. } \\
32 \\
40 \\
45 \\
56 \\
61 \\
72 \\
80 \\
96 \\
101 \\
120 \\
123 \\
114 \\
152 \\
160\end{array}$ \\
\hline
\end{tabular}


The comparative study of Table I of surface-sea waves with Table II of deep-sen wares will show the wide differenco between the two in time, speed, length, and nature.

The surface-sea ware is comparatively short and high. The deepsea swell is long and low.

The surface-sea wave of $4^{\prime \prime}$ has a speed of 14:28 feet. The deep-sea swell of $3^{\prime \prime} \cdot 14$ has a speed of $50 \cdot 26$ feet.

The mass of water in a surface-sea ware of $4^{\prime \prime}$ may bo 200 feet. The mass in a deep-sea swell, of like time and height, may be 700 feet. $^{2}$

\section{Under-Water Mrotion in Deep-Sea Waves.}

The remarkable characteristic of under-water motion, in deop-sea wares or ocean swell, is that the motion is all ono way.

In deep-sen waves the motion of the water-particles is forwards, in the way the ware is going. This is why it drives drift from the bottom of the sea towards the shore, and there heares it up.

An up and down motion is combined with this forward motion, but there is no backward motion.

The motion of the water is, as it were, a semi-circular leap forward. (See Figs. 21, 22.)

Frg. 21.

Shape of Ground Ware.

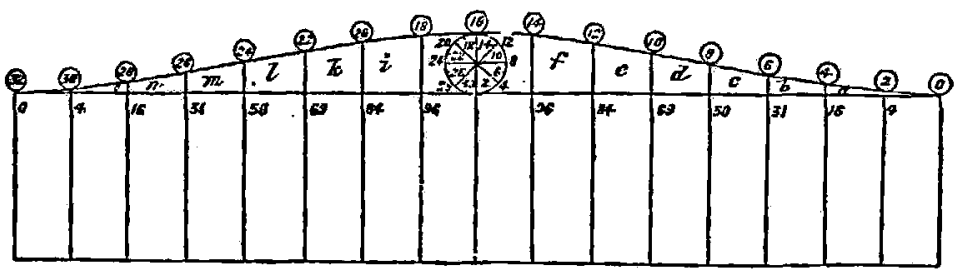

Fra. 22.

Water Columns in Ground Tare.

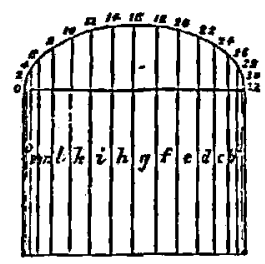

This circular leap forwards and npwards is flatter near the bottom and rounder near the top of the water.. (See Fig. 22.)

1 These numbers are the weight and rolume of cach foot length of the ridge.

Reckoned for cach foot along the mare ridge. 
Fra. 22.

Water Columns in Ground Ware.

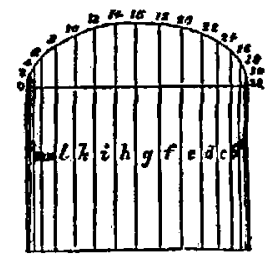

But the particles in the same upright line leap all at once, spring cach a different height, but leap all the same distance.

The time the leap of each particle occupies is the time of the wavelength. All, in one upright colnmn, start at the beginning of the wave and alight at the cnd in perfect rest, and remain there until another wave follows.

This leap is the motion of translation cansed by each deep-sea wavo on ground swell. There is a permanent change of place in the water; not a passing change.

The distinctions between the under-water motions of surface waves and of ground swell are best expressed by saying that, while the water particles in the surface wave move in complete circles of rapidly diminishing size, the water particles in the decp-sea wave move in half circles, gradually flattening, but not dininishing in span, all the way down, as shown in Fig. 22.

\section{Complications of Waves in a Storm.}

If there were only one single gromp of wares in one steady strong breeze, I do not think that their growing size, however great, would serionsly endanger a good ship. It is the complication of different sets of raves, coming from different sources and in quite different states, which produces confasion, chaos, and danger. A sailor knows fall woll how to lay his ship's head for a single set of waves, and is not afraid of their behaviour.

To understand a complicated sea, let us begin by conceiving a long low deep ground swell to have set steadily in upon a smooth sea. The waves are long, low, and gentle: We are in 48 fathoms of water. Wares, 6 fect high, swell gently upwards, 600 yards long, from crest to crest, and pass us, three in ench minute. There has been a storm somewhere. The long, low wares of the swell arc travelling 60 miles an hour; so that a storm, 360 miles away, may be coming towards us, and, as storms travel from place to place much slower than these waves, wo have some hours to propare. If we are in the Bay of Biscay, where I have watehed them, these swoll waves may be coming from the north-west.

By-and-bye, a smaller second set of waves sets in, shorter in time and space, from the north, and crossing the ground swell at four points, we have one set of wave-ridges overlapping the others and many more 
in the same space. This is a much nearer storm, as these surface wares are fresher and travel much slower than the ground swell. They are fire to a minute, and over 600 feet long. They only travel 32 miles an bour. They come from a storm much nearer.

We have now a ground swell of wares thrce to a minute and 600 yards long: and also a series of surface-sen rares firo to a minuto and 600 feet long. If they were all in ono direction their combination would bo simple, as the surface waves would more along the ground swall just as though it wero still water. But. as they cross at a difference of four points of direction their crossings aro more complex, and not easily seen in one plane.

Now the storm has come nearer, the wind blows from the north-east with violence, and the waves are now shorter, sharper, and quicker. The third group of sea waves are square across the second, and at four points from the ground swell. It is these last crossing the others, being crossed by them, changing direction with the chopping wind, and whirling about with the eddies of the blast, and over-riding the two previous scries of wares, that make confusion twice confounded.

\section{Storm Brealiers and s'hore Breatiers.}

Up to this point we have had the storm nearing us and gradually growing, but we have not yet had the worst of it.

So long as waves are of certain limits in size, even three or more discordant groups might co-exist without dealing destruction to ships or to ench other.

But when we pass the breaking point, destruction threatens equally the wares themselves and the ships they carry. It is necessary now to study waro breaking: whence it comes, and what it means.

\section{The Shore Brealier.}

The shore breaker is the deep-sca wave rushing to destruction; to anderstand this we must go back to the beginning.

I told you that the surface of the sea has a skin corering-of great density, very tough, bat rery thin. On it the gentle winds make wrinkles or skin waves - the biggest wrinklo is about 2 inches broad, and it requires a force of some 4 lbs. to the square foot to tear asunder the skin.

I asked yon to conceive of water in the sea as thongh it were so much liquid stuff stowed away in india-rubber sacks all set up against each other, upright in rows all pressing each against the otber. This allows these bags to be squeezed out of one shape into another, but without any of the water which fills them erer getting out of any of these bags. There is no loss or waste so long as this condition is kept.

Waro breaking is really the breaking up or the bursting open of these water bags. When the bags are burst open, the drops of water no longer hang on by each other. Every drop rashes. off on its own wild way; time in motion is no longer kept-all bond of :order. is 
gono; thousands of atoms of water are tossed about in wild confusion.

The reason of this I will now show in the deep-sca wave. We know the speed of a deep-sea wave, it diminishes in a given ratio to the dimination of the dopth as the water shoals towards the shore. In 48 fathoms of water our deep-sca ware is going 60 miles an hour, and may bo 6 feet high. In 20 fathoms water it is going 40 miles an hour, and its height is above 12 feet high, and has slortoned to half its length. In 9 fathoms water onr ware-speed has gone down to 30 miles an hour, and its hoight gono up to 25 feet. - In 6 fathoms water the ware will bo 36 feet higl, and from that point on towards tho shelving shore there will be one continuous breaking cataract, pouring the whole volume of the water it contains ont of the burst bags which contained it until evory drop has been dispersed, and all of them laid ont in a great white foam along the beach, or thrown up arainst rock or beach or breakwater with a riolence which will mako the deluge spring up 30 to 40 feet high, dealing out destruction or scnd the frittered spring in magnified recoil 60 or 100 feet up on the cliffs.

That is what I call a breaker of the first order or deep-sea breaker. The reason of this destructive violent rupture and dispersion is this : the wave form has a certain fixed speed of its own; that speed in deep-sea waves is taken from the depth of the water; but the warespecd is quite apart from the speed of each atom of water. The wave las its own speed, but the water has quito another and a much slower speed. Thile our wave was going 60 miles an hour, the water atoms in it were going less than 16 feet $a$ second; but as the wave went on to the shallow it went slower and slower, whilo the accumulating mass in the shortening and rising up wave becamo.higher and faster, and in doing so cach water atom was compelled to make a higher and farther leap. At last the wave-motion showed so much, and the leaps of tho water particles grew so high, and they sprang so far, that the wavebags burst, and each water-particle going higher and further than the ware conld follow it there was an end of common movement and common bond, and each water-particle rashed with its own speed and force wildly spent against whatever obstacle, rock, ship, cliff, or beach came in its way; the water became a wide-spread flood, and tho wave had ceased to exist.

\section{The Storm Breaker.}

That wave we have just followed from the deep sea may have been originally a surface-sea wave, generated by wind far awry in tho fathomless ocean, and slowly transformed by shallowing depth into a wave of the deep or ground swell.

But there are also breakers on the surface of the sea in wares which never reach the shore, nor go so deep as to feel the bottom.

How they come to break we slould now examine. Fior the study of this subject we may take a wave of each kind. (See Fig. 11.) 
4 Surface-Sea Breaker.

Fia. 11.

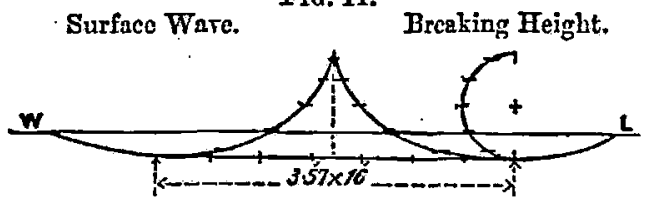

\section{A Deep-Sea Brealer, or Ground Sicell Brealier.}

Waves which feel the bottom of the sea only break by shallowing in the following fashion: as the water shallows thoy shorten, as they shorten they rise. When the shallowing depth and the rising height of wave become equal, breaking begins, and goes on as long as the water shallows. If it deepen again, the wave will cease to break, will diminish in height, will increase in speed, and grow in length, and resumo its' first speed and bulk.

The reason of this equality of height of breaker and depth of water is, that the speed of the ware depends on the depth, while the speed of individual water atoms depends on the height, and both in such manner that when depth and height become equal, the water speed equals the wave spced, that is, the condition of tottering equilibrium, after which the slight excess of height of wave or diminution of depth upsets the balance, and the faster motion of the water atoms removes them ont of the wave, and severs the bond between it and cach other. Tho waro diminishes rapidly as the water leares it and floods the shore, and once the water-particles are dispersed, and their time-kecping movement and wave-line bond is broken, the water becomes chaos and the wave ceases for erer. (Seo Figs. 5, 21, 22, 23.)

FIG. 5.

Standard Decp Water Ware.

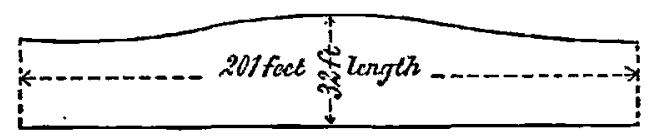

6.28 seconds time. Specd 32 feet".

Limiting ware height $=$ Still water depth.

IIeight of ware-crest abore water bottom, 32 feet.

Fia. 21.

Shape of Ground Ware.

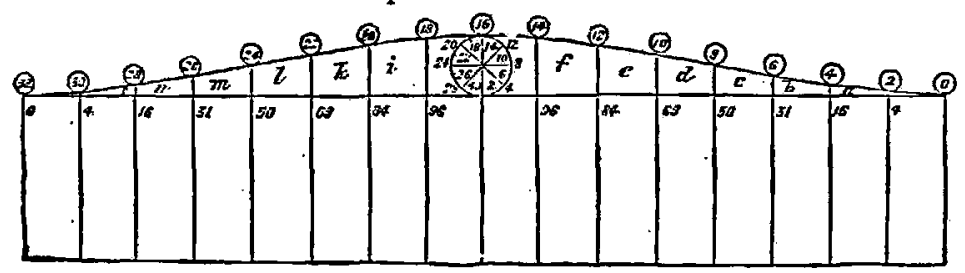


Fra. 22.

Water Columns in

Ground Wave.

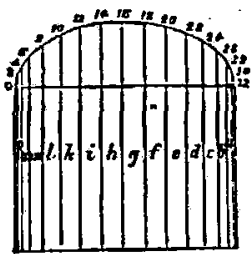

Fra. 23.

Water Mass mored during

Ware Transit.

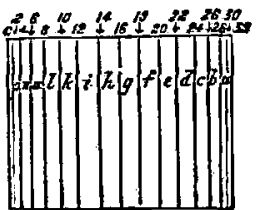

How the IVind Creates Breakers.

The direct pressure of the wind on a square foot of ware surface is -

$1 \mathrm{lb}$. for 20 miles an hour.

4 lbs. for 40 miles an hour.

9 lbs. for 60 miles an hour.

This is the result of my many exact measurcments; it is more moderate at high speeds than the measures of others, which I think arises from errors in the instruments they used, and to these crrors my instruments were not liable.

One cubic foot of salt water weighing $64 \mathrm{lbs} ., 4 \mathrm{lbs}$. is the sixtecnth part of the weight of a cubic foot of wave. This force could communicate a speed of 2 feet per second to 1 foot of water in one second of time. Supposing then a surface-sea wave 4 feet high and 64 feet long to bo attacked by such a wind, and taking the mass of 1 foot section to bo 128 cubic feet, it would have a speed of 2 feet a second given to it in 32 seconds of time, or about half a minute, and in littlo more than 8 minutes it would be raised to 16 feet high, and have a speed of 32 fect a second; it might become a violent breaker, and might contain 7 tons of solid water in each foot of ridge-length, which, projected over an impediment, a ship or rock, would deliver a stroke of 20 miles an hour speed with a weight of 7 tons. If it were 10 feet wide along the ware-ridge, it would deliver a shock of 70 tons at 20 miles an hour, equal to the stroke of a railway engine collision.

\section{Storm Traves and Stable Ships.}

I think we may take it as the definition of a storm wave on the surface of the sea, as distinguished from a gentlo wave or smooth swell, that the hollow below the water-level is the same depth as the heap of water is high above the level in moderate weather, and with moderate sea. But in the storm the wind drives the water-heap up to a sharp crest, which is three times as high as the hollow is decp. Thus the swell may be $\frac{1}{2}$ to $\frac{2}{8}$ of the wave-length in height without storm waves being directly created; but when this height is suddenly doubled by a sharp crest, driven up to near $\frac{1}{4}$ of the wave-length in height, the storm waves become breakers, and may be a source of danger. (See Figs. 11, 12, and 13.) 


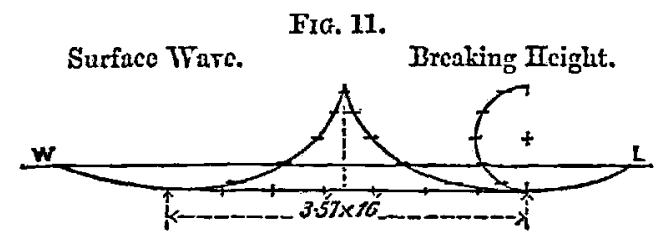

FrG. 12.
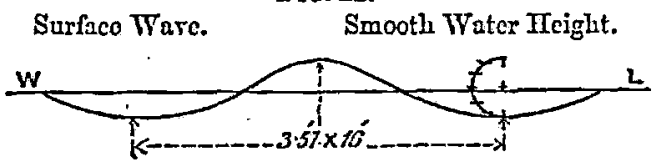

Fic. 13.

Surface Tare. Subsiding to Ground Swell.

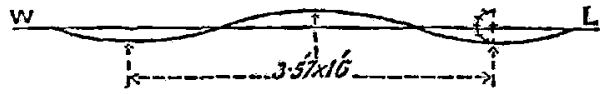

This rapid doabling of the height and sharpening of the sliape by the violent wind, makes ench individual wave a souree of danger; but this danger becomes exaggerated by the complication of several series of waves in several directions at once, and each of these can monnt on the top of the other, and so prodnee its own destruction as well as aid in the others.

Threc causes lead to danger waves and breakers :-

1. The wind sending up tho wave crest to a height tro or threo times greater than the holjow.

2. One ware summit rising on the top of another.

3. The water shoaling under a ground swell.

We have now seen enough of the shape of these waves, and learned enough of their ander-water motions, and measured sufficiently tho force of the wind on the waves, and the moving power imparted to the huge moving masses, cspecially when breaking, to be able to appreciate their effects on ships.

"The Rock" (Fig. 2), "Tho Raft" (Fig. 1), "The Ship" (Fig. 3), are the three types we have taken as representatives of "smooth-water "stiffness," of " rougli-water stiffness," and of the "storm stability," of which wo are in search.

Take the rock of 48 feet beam, and 29 feet draft.

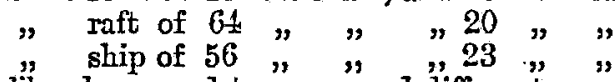

all of like shape, and tonnage, and different proportion.

Tho first with its weights very low.

The second with its woights very high.

The third midway.

Tho first would be steady and stiff, and would stand upright under canvas both in rough and smooth water. But it would bo uncasy, and in a storm would bo struck heavily by violent waves without 
yiclding, and might therefore suffer great damage in a storm by injury done to her structure; she would be struck like a rock by the sea.

The second would bo stendy and stiff and upright in smooth water, and stablo in gentle waves, but would roll dangerously in a beam sea, would take in on deck the entire volume of storm sea wares, and might capsize.

The third ship, well trimmed, might aroid the dangers of the other two by good proportion and wise shape, which we shall now seek.

\section{On Ship Shape.}

That a good searrorthy safe storm conqueror may bo constructed with high storm stability and gentle easy motion, so as to be neither rock nor raft, I can venture to assert as tho result of many years of experienco and observation. I cannot claim originality in such forms, as they are a tradition from the former generations of searrorthy shipbuilders, and. were expounded by the most distinguished of our philosophers and mathematicians. But $I$ have arrived at their conclasions, although procecding on quite different data, and following quite other methods of research.

In order to find out the most perfect form of ship for storm stability, I take a form of no stability, and then I seek to give it only that kind and those degrees of stability which $I$ want.

The typical form of "No Stability" is the circle. A circular body, or barrel-shaped midship section, has the wonderful quality of absolute nentrality, of perfect indifference to attitude, and is equally endowed with stability or instability in a smooth calm or in a raging storm.

This quality of perfect noutrality in all seas is just that quality which enables us to handle it as we please, and give it just the degreo and kind of stability we want.

If we take this round or barrel form and place in it, without change of shape, a very small portion of ballast, this small bias will ensure the circular form remaining always upright, even on the most troubled wares.

Supposing then such cylindric midship body to be weighted with sufficient ballast to bear up under the pressure of sail, by ballast alone, the waves would roll all around it withont disturbing effect, excepting the two effects of rising and falling, pitching and scending. Its masts would stand ap steadily under due pressure of wind, only.inclining over to the due angle and press of sail.

But this shape and trim would have one fault. We do not wisl a ship to stand upright, or to havo a fixed and changeless inclination on a heavy sea. Wo wish our ship to careen gently over with tho slopes of the swell; we wish our deck to conform gently with the slopes of the wares; we do not wish it to follow the violent changes of storm waves into their extreme and dangerous slopes; we wish our ship to stay half way between.

This medium motion wo mnst now try to gire our ship so as to stay equidistant from rock stability and raft stability.

The form which unites and reconciles these opposites we obtain as follows:- 
Tako a circular midship body of no stability-place it afloat at tho intended draft of water-arrange all the weights so that the centre of weight shall lie in the centre of the circle-place all the heavy woights at the nearest convenient place to the centre of tho circle-place no weight further away than is indispensable to its use.

This circular body is now alloat, carrying all its own weights, but entirely free of stability of any kind (see Fig. 18).

Frg. 18.

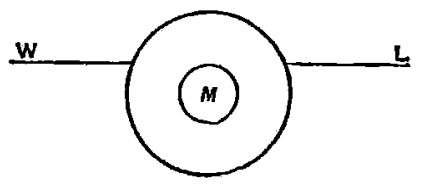

Fra. 10.

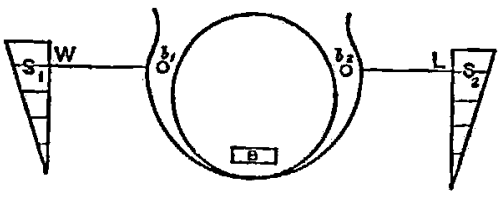

Fia. 20.

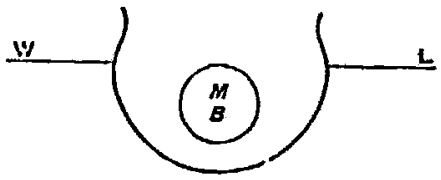

Next, take two triangnlar forms, which I call shoulders- $S_{1}$ and $S_{3}$, Fig. 19-add these two areas of section to the circular section, then place low down in tho hold their equiralent buoyancy in mass of ballast.

Thus, two sources of stability haro been given to the nustable circlo-shoulder stability and ballast stability, and an equal quantity of both.

Now, this shoulder stability, being only half of the whole stability, will give the ship easy motion on the waves and with them.

And this ballast stability will give the other half wanting to keep the ship vertical and maintain the action of the wind on the sails.

Thus we have halved each of the kinds of instability to which the ship is liable, and have provided the complete whole of stability the ship requires, and thus we lave minimized the movements of tho ship with the sea and minimized tho careening power of the sails.

The size of these shoulders of the ship and the place of the ballast aro matters of exact calculation, and must be suited to the purpose of each ship.

But, in modern steam ships, there are so many large and weighty 
masses of matter, the wiso placing of which should bo at the disposal of her designer, that no difficulty in disposition of weight should require the ship to be burdened with valueless weight. Engines, boilers, water, and fuel givo ample ballast, but they are sometimes unwisely placed, and do harm.

It will be readily seen: how this form, with its opposito halves and natures of stability, will have compensating natures of force within itself, preventing either motion becoming exclusiro or excessive, and, therefore, the tendency to oscillation through large arcs from internal canses is minimized.

It will equally be seen how this circular form evades all the forces from causes external to the slip tending to give it rolling motion. In all the classes of wares, wo see that the under-water motions are circular. If, therefore, our ship were of an angular shape, or if it possessed the strange deformities called bilge keels, we could see how the circular vertical oscillations of water-masses in wave-motion would strike on these projections, with violent concussion or with accumnlating friction, and how the waves would thus first communicate to the ship violent rolling movements and then, by contrary violence, bring it back to rest, thus performing much useless work and involving much waste. Bnt the stable circular form has neither an instrament to disturb the freo oscillation of the water in its wave circles, as they surround and embrace its body, nor has it any protuberances, corners, or flat boards upon which the rerolving water masses can deliver their blow.

This form, therefore, has no internal source whence to obtain rolling and dangerons motion, nor has it any external instrument by which to impede or take up any of the storm forces raging around.

\section{Conclusions.}

I trust I have now answered all the questions I undertook.

1. A storn is that state of the sea where waves, which had equal height and hollow, have been driven so high that the height above the sea level is near threcfold the depth of the hollow.

2. Smooth water on sea is not necessarily level water, bnt, so long as the height and hollow of the wares remain equal, it may bo reckoned smooth water.

3. Stiffness is the ability which a ship shows to resist the tendency of wind and sails to incline it over from the water surface.

4. Stability is the ability a ship shows of not taking from the water the rapid changing attitudes which the water itself assumes in storm waves.

5. A storm is created on the surface of the sea by the excavation of a hollow from the level-water surface, and by the piling up of this excavated mass in the neighbourhood of the hollow. Theso two aro always of equal volume. The force of the wind measures the height of these wares.

6. Smooth water returns after a storm, first by the descent of the ware crests from their threefold height to their equality of height and hollow; next, by the spreading of the heaps and hollows more and 
more wide, until they exhaust their force on water friction, or til they break up on the sea shore, or until they create other waves, which take off their forec to a great distance.

7. A stable ship is made by moderate beam, due depth, and by such shape and reight as neithor to oscillate from internal canse nor to suffer injurious movements from without, which stands up withont becoming uneasy, and leans over gently without jerking against tho trares.

8. $A$ ship is made stiff either by much beam or by much bottom weight; the least quantity of either that fulfils the useful purpose of the slip, is the best.

9. The nature of surface-sen wares, as distingnished from the nature of deep-sea mares, is that thoy do not agitate the water much below the surface, however violent their motion may be on the surface. A ware 36 feet long, oven if 9 fcet high, would produce scarcely any motion 18 feet down; the motion of such a wave 36 feet long would not ordinarily be more than 4 feet, 2 upwards and 2 downwards, except in a storm. Whilo each water particle mored 2 feet up and 2 feet down, it would also move 2 fect forwards and 2 feet back, thus performing vertical circular motions with steady speed. While the wave seems to fly onwards, the water really remains going round in a place either fixed or slowly changing.

10. The nature of breaking waves is this: that whenerer the force of the wind is so great that the separate particles of water sent up into the summit of a storm wave recoire a more rapid motion than the ware form already has, the particles moving faster than the wave, upwards and forwards, leave it, take each their separate way, and the wave is dispersed, diminished, perhaps destroyed. Or, if ono ware orertops another, the like effect takes place.

11. The ground swell differs from the surface ware in the fact of the motion of its particles descending all the way down to the bottom where thes go as far forward as at the top; they go all forward and none backward; there is no hollow below the water level, and each wave is a large heap raised above the standing level of the etill sea. They break, whenever the depth of water equals their height.

12. Storm wares are surface wares which, instead of having equal heights and hollows, have the water sent $a p$ by the foree of the wind to a sharp crest, which breaks when about three times as high as tho hollow; and, also, those waves which, by the force of wind changing direction, are driven to ride on the top of each other, and are driven over and clash and mutally destroy cach other or the ship they strike radely or which rudely strikes them.

13. A crank ship should not exist; it generally comes of narrow beam, or too great depth or top weights; it inclines far over with light wind or none; it makes long and heavy swings; it is dangerous, and only high frceboard can save it. Bottom weights lowered down or sent in are the common cure.

14. A stiff uneasy ship is the contrast to a crank ship. I haro sometimes seen a crank ship mado the better of the two; the crank ship yiclding slowly and gently to the wares, and rolling too much, 
bnt casily; while the stiff ship, with its own inside weights, was jerking with violent, short quick blows, from side to side, in collision with the waves. The removal of weights from places where they givo and get violent motion to those places where they will more more slomly round a stable centre is the cure.

15-22. All these questions are already solved by the shape of ship shown in Figs. 19 and 20, and the distribution and stowage of weights as near to the centres shown as is consistent with the purposes of the ship must govern the rest. The evils we cannot aroid we ray at least minimize.

\section{DESCRIPTION OF THE FIGURES ATD DTAGRAII.}

Fig. I shows tho midship section of ship which is stable in smooth water and unstable in a heary sea.1

Fig. 2 shows the midship scetion of ship which is too stable in all weather, and requires to carry much heary weight low down. It is nerer casy, gentle, or live!s, and is alrays fighting riolently with the wares.

Fig. 3. Tho ship shope is alwass easy and lirely, stablo and gentle, horing the exact measure ranted of surface stability for snooth rater, and of uprigliting stability for rough scus in a storm.

Fig. 4 is the standard surface ware. Each particle of water on the surface mores once round in a tertical circle during tho samo time while the crest of the ware mores forward. Just as a whecl goes forward while cach spoko gocs round, so ench particle of mater goes round a circle the mas the ware is going in the same timo in which the waro goes forward through its own length.

The Diagram (Plato XXXT), shows the details of water motion and of ware motion in a model surface ware, from which (as also from the standard, Fig. 4) the other wares may be calculated and measured. Sce Table I of surface wares.

This Diagram lass the rertical columns of still water shown by upright lines. Theso lines sway back and forward at bottom and top of cach ware. The rater columns lengthen and shorten, while the top of exch rater column goes round a circle and at a certain depth below stands still. The water columns smay back in the hollow of the ware and swing forward on the crest. The motion of the ware is uniformly forward, the motion of each water-particle of the surface is uniformly round in the eircle, and the riso and fall of the water corresponds exactly to the times and heights of the uniform circular motion. In short, the motion of cack single rater-particle corresponds to the motion of the hand of a clock, and kecps time with equal truth.

Fig. 5 shows another ware of quite a different nature from the surface ware. It is ealled the deep-water ware as distinguished from the surfaco Tare, becauso the rater in it mores 29 much at the bottom of the water as at the top and almays forward, instead of backwards and forwarcl.

It is called the ground swell because it alrajs feels the bottom and tells the eye which can read its meaning, how deep the rater is. It is sometimes called the raro of trauslation because it carries things forward the way it gocs. Figs. 21, 22, 23 show the details of the deep-water warc.

Fig. 6 shoms how surface wares are created. Wind or other forces scoop out a hollow, and the water resists, and pushes up rater from below to fill up the hollow.

Fig. 7 ghows the water below springing up to fill this hollow, while from both sides the water also flows in to fill it. These three meet and spring too high and fall down again.

Fig. 8 shows tho water rising full swing upwards aboro the lerel forming a heap, while the tro sides whence tho water flowed into the first hollow are now emptied out, and two hollows remain on cach side.

Fig. 9 shows a new state of things, results of the former. The central heap falls; the side hollows are filled from below.

Fig. 10 shows a stage further on. One central scoop, a couple of heaps on cacis 
side, a couple of hollows formed on cach side of these, and so this process goes on in odd numbers of rares:-

One middle one.

A pair of side ones.

A second pair of side ones.

A third pair.

Thus making :-

$$
\begin{aligned}
& 3 \text { wres in a group. } \\
& 5 \text { wares in a group. } \\
& 7 \text { wares in a group. }
\end{aligned}
$$

And so on, either groming up or dying out, according as the moring force of tho rind strengthens or dies.

Fig. 11 shows the surface ware with its tro side scoops when it reaches its breaking height and becomes a storm ware. In this diagran is shom how the water scooped out of the hollow is piled up three times as high, and forms tho summit load of tho waro just before it breaks.

Fig. 12 shows how if the wind falls this ware subsides; diminishing its height till it is only the same height as the hollow is deep.

Fig. 13 shows how this equal height and depth continue until the maro disappears.

Fig. 14 shows the rolumes of mater mored.

Fig. I5 represents tho places where they are mored to, in order to be set so as to form a ware.

Fig. If shows the order in which these heights and hollows must be set to form a continued series of wares in smooth water.

Fig. 17 shorrs tho new attitudes these samo masses take in a storm. Tha hollows remain unchanged in attitude, but tho heights are driren nearer and set upright to the extreme of three times the hollow, after which they break down and become scattered.

Fig. 18 rcpresents the form of absolute indifference, which may be called equally the form of no stability or of no instability. It is tho form which the rater does not disturb and which does not disturb tho water-the slightest weight below its centre will hecp it upright. It is a perfect float for carrying heary weight placed around its centro $(M)$; but is not a ship.

Fig. 19 shows how to make it a stable ship in smooth water. Two shoulders on the two sides are added to the rolumo of the ship. The exact measure of stability you want is giren by the arcas of, these triangles and by the place of their centres when in the water, and thus the required measure of power to carry sail in smooth water is directly obtained.

Fig. 20 shows the shapo of midship section of ship which is thus obtained. But as we hare added to the rolume of the ship the addition of the shoulders, we must now also add to the former load carried so much additional load in cargo, stores, or ballast. In placing this new weight we must either place it low domn, so as to double the power of the shoulders in still water, or, considering it as part of the whole lading, wo must lower the whole lading down to the place where it will produce a like effect. We hare thus got our whole sfability in two halrcs; one half in the power of the shoulders keeps the ship normal to the surface of the water, the other half, in the equiralent weight added below the centre, or in the whole weights lowered down, tends to keep the ship upright or sertical without reference to the water surface or ware surface. Thus, in still water both actions help to kecp tho ship up under cantas; in surface wares the ship is both stable, lively, and casy ; in storm wares the uprighting stability steadics the ship, and the surface stability gires her ensy gentle morements. Thus, in Fig. 20 wo haro the shape and the stowage of weights and ballast (AI and B) which gire equally storm stability and smooth-water stiffness.

Fig. 21 gires the shape of the deep-mater waro or ground swell alreads described in the standard in Fig. 5, and here much enlarged. The circle in the centre represents time by the hand of a watch going round. As that hand goes up and down and round the circle, so the water surface riscs and falls, and goes formard along the line, keeping true time and exact height. The times are shomn in instants on the 
curre, as $0,2,4,6,8,10,12,14,16$ instants rising up, and as 16,18, 20,22, 21,20, $28,30,32$ instants falling down.

Fig. 22 shows how the water is moring in the deep water while that ware is moring along the surface. The water at rest is in rertical columng and these columns remain rertical throughout the ware transit. The figures abore, $0,2,4,6$, $8,10, \& c$., show how these columns march forward in the deep, while the wase on the surface glides along, as shown by the same numbors in Fig: 21, all keeping true time.

Fig. 23 shows the result left behind the ware 21 after it has passed array. All the water columns shown there hare been marched forward out of their former place where they rested, and set down in a new place that length forward and there left at rest esactly as before. Fig. $23 \mathrm{is,} \mathrm{therefore,} \mathrm{a} \mathrm{series} \mathrm{of} \mathrm{columns} \mathrm{as} \mathrm{found}$ at rest and left at rest, and Fig. $2 \%$ shows the samo series of columns as they are while on the more, under wave shape, Fig. 21.

Admiral Fismiodnxe: Wo are rery much indebted to $\mathrm{Mr}$. Scott Russell for his rers clear and lucid exposition; his distinction between smooth-water wares and eea wares shows the real cause why there are such diversities of opinion with respect to the performanecs of ships. That has been entirely lost sight of, so ships lare been compared in conditions that are totally diverse, and it is often assumed that because a ressel conducts hersclf well in particular circumstances, such as smooth nater, she vill necessarily conduct herself well in other circumstances. This is a dangcrous mistake. We bavo nerer had the exhaustive examination of models when first produced, that we ought to hare had. Examinations are not so extended ns they ought to be; moreorer, the persons carrsing them out are continually changed; thus they are all learning their lesson instead of haring experience and standard by which to measure.

Commander Cerrrs, R.N. : I should like to make a few remarks with respect to that ressel that Mr. Scott Russell called the "Rock; " in nautical terms we should call it a half-tide "Rock." There wero six ressels fitted out in Dundee or somo port in the North, to go to the Yang-tze-kiang in 1861, which wcre called clipper barques, of great length and light draught, laden with railway iron, and I thing from hearsay there were only two that erer arrired at their destination. One put in at Rio, she washed ererything off the deck, rolled so that she flapped topgallant sails out of the bolt, and when she arrired at Rio she had to put bilge pieces on and to raise the ballast. I think you will recollect that when Mr. Porter the other day at the Society of Naral drchitects read some interesting reports about the load line, somo gentleman sarcastically remarked that the load line might just as well be on the maintop for all the use it was, and $I$ think he was nearer the truth than is generally imagined. If you look at the papers every day, jou will find, $I$ think, that we lose on an arerago one ship a-day by foundering. The fact is, $I$ suppose, there is very little strbility in the way of stiffiness on account of the disposition of the weights in the ship, ${ }^{1}$ and they are really capsized in the trough of the sea. I agree with MIr. Scott Russell that the disposition of the ship's weights should bo such that with her engines and 20 tons of coal, and boilers full of water, ehe ought to be ablo to etand up under her

1 Sec Standard, May 21st, 1879. Missing ships between Americe and Englandsinco 1841 - number lost 145-26 missing, 80 wrecked, 6 foundered, 8 abandoned1 capsized, 11 burned, and tho rest sunk by collision.

Fire nem iron steamers lost this scason were laden with grain, bearing out what I say, that grain laden ressels hare rery little stability, especially if they hare compartments for acater ballast, and those compartments empt5, which $I$ believe is the practice when laden, it tends to make the ressels top-heary-and they are orerwhelmed with the sea before they can right themselres. The paper remarks, "It secms hardly to admit of any doubt that a class of stcamers hare been "jlaced in the Trans-atlantic freight business mhich are not adapted for stormy winter "seas, or else there has been gross neglect in loading."-J. D. C.

FoI. xxIII. 
cantas, I do not say in a gale of mind, but steamers going from ono port to another for cargo may be reduced to 30 or 40 tons of coal, and hare to depend upon the eails, in case of losing the ecrem, not infrequent in merchant stenmers. To gire a false bottom, I think makes the ship reak, and water is an objectionable thing to hare in a ship, becanse you nerer know where a leak will be. The true ballast of $n$ ship should be her engines and boilers, and sho ought to be able to stand up under her canvas. I should like to say just one nord about wares trarelling. I know that running round Cape Horn, we often had rery great fears of being pooped by tho wares.

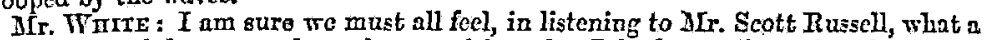
master he is of the porrer of popular exposition; but I think eometimes that the wealth of his illustrations makes it more difficult to say anything that is critical concerning them. If, therefore, I now raise a question ns to one or two of the "standards" which IIr. Scott Russell has giren, I know he will tako it that I am asking for information, and not disputing his obserrations. I lave not the opportunity which he says he has had of personally obserring wares at sea; but I hare had the opportunity of studying the obserrations made by many naval Oflicera in the French, English, and American Narics, and I find that the law connecting the length and period of wares is not that giren on Mr. Seott Russell's tablo of "standards." Instead iof the factor giren by Mrr. Russell-the conrenient number for memory 357-I find that factor more nearly approachics tho figure 5 . In fact, taking the aremge of a rery largo number of observations, I find tie so-called "trochoidal" theors (which would give the exact figure $5 \frac{1}{4}$ ) is as ncarly as possiblo confirmed. If any gentleman will turn to Mr. Antoine's long list of obserrations which hare been recently published, he will find that having compared obserrations made in the French Tavg, wilh Dr. Scoresby's obserrations and all tho other obserrations on record, French miters have acepted the trochoidal law as their standard, and this makes $5 \frac{1}{3}$ times the square of tho period equal to the length of the wate.

MIr. Scotr REsseLs: What is tho seconds mare?

IIr. WIIrE : Fire and one cighth feet. I do not mean to say that they have erer obscred a ware haring a second period at sea; I mean to say taking for crample, wares of six seconds period, those wares would bo orer 180 feet long instead of being, os Mr. Scott Russell has it on his table, 128 feet long. Only to-day I happened to talie up the obserrations made on board one of the ships which Sir Cooper Key has recently had in his equadron in the West Indies, and I found a record of wares of cight ecconds period orer 300 feet long. I only gire you these as instances confirming my statement that the rery extensire obscrations made in the last few years by naral oflicers do not agree with the standards gireo by MIr. Scott Russell. Then as to Mr. Russell's "pattem ship" I wish to say one or tro words, from tho naral architect's point of riew. Mr. Scott Russell knows as well as any one that jou could not possibly point to the circular cross section, thoso " ehoulders," from which he lopes to derire such benefit, without affecting the position of tho metacentre of tlic ship.

MIr. ScotT-RusseLL: I hare aroided metacentre.

Mr. Wurte : I knomit is aroided in terms, but it is thero in fact. $I$ am accustomed to speak about the metacentre; $M r$. Scott Russell is accustomed to speak about the shoulder; we mean the same tling. But I must add that the whole effect of the shoulders is not counted up when you take account of the consequent alteration in the position of the "centre of buoyanes" Mr. Scott Russell will admit that, I am sure. The truth is when you join to a circular cross scetion scctions which are not circular-

Mr. Scotr Rtsablu: Of courso I raiso the metacentre, I assumed ererybody know that.

Mr. WiIte: Then raising the metacentre-

Mr. Scort RcsseLI : Gives me exactly the buojancy I want.

MIr. WHITE: It also takes away the rery admirable quality mhich the circular cross section has, riz., that all the external huid pressures are then delirered through the axis of rotation. If you hare joined to the circular cross section those shoulders, jou must lose that quality; I haro been for a good many jears connected vith the 
designing of steam ships with rery large engine powers and "disposable wcights" as Mr. Scott Russell puts it. Otr diffeulty homerer usually is to get the boilers and engines into ships at all, in conrenient places; in ohips of war, for instance, it is necessary to place the machinery under the wrater line, or under the protection of the armour. It may bo different in merchant ships; I do not pretend to say much about their design, but it obriously embraces other and special considerations. But in ships of nar, most certainly, from not a small cxperience I can assert that our elief dilieulty is usually to get engines of tho necessary power into tho spaco arailable under the necessary conditions. So that, the rertical distribution of tho weights of the machinery is not a thing which helps the naral architect so much as Mr. Scott Russell seems to suppose in goreming the position of the centre of grarity. On a prerious occaeion in this theatre I remember $\mathrm{SIr}$. Scott Russcll also made similar statement as to the effect of the disposable weightits of machinery and boilers, and therefore, I now take occasion to say that in our cxperience in war-ship-design, that is not a thing that helps us to anything like the degrce MIr. Scott Russcll would suppose.

As to the general claraeter of Mr. Scott Russcll's remarks I join in expressing the thanks that we feel. I think his remarks on wave motion, in the main, express the riews of all the most eminent authorities who hare mritten on the subject. Of course Mr. Scott Russell puts his diagrams forward simply as rough indications of the intermal structure of rares; but I must say this, that tho breakers that Mr. Scott Russell has put on the board (or wliat tre usually call "cjeloidal" wares) aro not the wares which eailors tell me often produce the most extreme rolling in large ships. And furthor I would say that the eceond "objectionable" type of ehip, according to Mr. Scott Russcll (his "half-tide roek" tJpe) is pretty nearly tho ection of many existing merchant ships; and $I$ am told that those elips, although rery decply liden in proportion to their beam, as a rule behare crecediugly well. I am now speaking of sueh ressels as the Atlantic liners which would often haro 27 feet of draught on starting, with 40 to 45 fect beam-a proportion of dranght to beam which in ships of trar is scarcely erer, if erer, secn.

Admiral SELTrx: I think, Sir, wo all join in our admiration of Mr. Scott Russell whenerer he rises to speak to us. His facility of manner, and his happy illustration, command attention, and giro us a great deal of instruction in a rery short time. As regards his observations on waves at ses, most of my brother ceamen will join me in sajing that one of the most diffeult things to answer a man can be asked who spends a long life at eea, is - What is the ordinars behariour of wares? One man will tell you that ho neter saw a waro abore a cortain height, and ho may hare followed the sea quite as long as another who has seen a great many rarieties much higher. It liappens perhaps to a young sailor, who goes to sca for the first time, to get into a liurricane, while another may follow tho profession his whole lifetime, and nerer come across one. And when we do come across hurricanes, this remarkable fact takes place, that although wo should like rery much if we wanted to see big wares, that the wind should blow orer us in one cortain direction for tho greater part of the time during its period of touching the earth, that is just what it neverdoes. Luchily for ships' existence, it is alwajs turning round, and creating cross scas, which compliente the problem so tremendously, that the closest observers will tell you that they have very rarely seen a really steady eca. I think it is rather a disgrace to the profession that we should now regard the obserrations made by Dr. Scoresby in smnll ressels, as our only standard of information on tho subject. I am quite sure, from my experienee in tho large Atlantic steamers, that they offer to us very considerable adrantages for obserration. Thes are of lengths which I will not say in the heariest Atlantic scas, but in most Atlintic scas, are not surpassed by the ware length. In tho "City of Richmond" and tho "City of "Chester," tro of the longest of the Inman Line-orer 400 feet long-I hare observed that the ware entering under the stern was coincident, as nearly as poscible, with the ware parting from the bow, with a following sca, in a gale of wind, at a epeed of $16 \mathrm{knots}$, and under those conditions the depth of the mare was often quite inconsiderable, compared to what might hare been seen in a hearier or a longer continued gale of wind. I regard the whole question of the action of the wares as one to be subordinated to the consideration of the downmard friction of $3 \mathrm{~L} 2$ 
cach particle or atom of water, that is to say, the power of the superincumbent water moring orer the lower water, and the frictional action so set up, to retard the mare. That there is a motion forward in obedience to the force excrted by the wind no one can doubt, but this is brought to rcst in rery large measure, as $\mathbf{M r}$. Scott Russell has shown, bJ that rery frictional action which raises the ware, and the trochoidal theory showing the circular morement resulting from the friction belor, is the nearest approach that has jet been made to the true morement of any atom of any ware. But with regard to the height to which wares can risc, Mr. Scott Russell must gire us the conditions. If it blows a gale of wind into the Bay of Biscay, lasting for a ccrtain time, the motion may be so fas communicated downwards, that the ware which rould not hare been a breaking wnre in the Atlantic, becomes a breaking ware in that depth of water owing to the frictional effect of the immorable bottom coinciding with the frictional effect of the partially movable water, and producing a break where there would only hare been a slight cone. With regard to the speeds of wares, it rould be rery useful if we could rule the wares in parallel lines, but $I$ quite agree in thinking that we may usefully study the question much further than We hare set done; that it is a fair reproach that the attention' of enilors has not been moro deroted to what their extremely accurate instruments enable them to do now much better than before, that is, to study the behariour of their ships in wares which will differ with erery form of ressel, with erery mode of disposing of weights, and also eren with the skill of the captains in mecting the wares.

With regard to the shapes of ressels which gire storm stability combined with smooth.water stiffness, I renture to say that wo hare done a great deal to weight our resscls unneccssarily. I am most happy to hear tho repetition by Mr. Scott Russell of an idea which has been long present in my mind, that lo was not fit to bo called a naral architect who puts ballast-useless meight-into a steam ship, particularly that that is the case when we hare to deal with iron and steel ships-he is not deserving of the name of naral architect, for he has not made the proper caleulations or he would not lare to put in uscless weight any moro than the boy who knows how to cut out his wooden model wcll, will hare to put a lead keel to the ressel to keep her upright. Now I want to know from Mr. Scott Russell is it a necessary part of the higher art of naral architecture that ships should have a normal position bottom up? Is there any good reason now existing more than existed forty or fifty years ago, why a ship ehould not be able to turn orer on her beamcads, and if you cut her masts away, or otherwise reliere her of the reclining pressure, come upright again? Is it or is it not simply due to a little want of coneideration of the necessities of the problem and giving too great a weight to the dificulties which ererybody must admit hare arisen? Armour and artillery are no. jokes; they hare come as a necessity upon the naral architect; they are weights which have to be carried high up, and the form of the ship must be studied to carry those weights high up. Being a necessity we hare to deal with it in that waj. It is all very well for the merchant ship-owner to say "I will load a certain quantity "of iron or other dead weight placed in a certain position, and I will carefully obserro "that the conditions under which that ship will behare well at sea shall be carricd "out faithfully," but the naral architect has that dreadful condition constantly beinge forced upon him that the weights of armour are increasing, the weights of guns are increasing, they all must be carried abore water, and crerybody is disposed, far from increasing the weights of engincs and boilers, to decrease them as much as possible, while the coal carried will almass also be subject to diminution by use. Now the question arises whether the forms of ships which were perfectly good so long as wo had only to deal with certain weights, wlich wo could disposo as we pleased, may not be usefully abandoned to a certain extent in riew of tho present difficulties, and I put it to MIr. Scott Russell as a question whether the only direction of mecting that difficulty is to make a ship so light below and so heary abore that if she goes orer to an arglo of inclination of 45 deg. in spite of ballast she will turn orer and go down. This is a question which interests not merely dilettanti, or old offecrs, it is a question of life and loss of life at sca, a question which affects for all future time the lires of sailors. We want a narigable ressel which will keep the sca in all weathers, and we do not want to be sent to sea in anything, which howerer beatiful, will probably or possibly encounter weather which will drown the ship and 
crew; and we do ask that naral architects shall gire us a ecaworthy sea-hecping ship, and we suggest to them that there are ways of doing it other than those we hare yet adopted of putting all the weights up abore, and all the buojancy belorr, and then compensating for the position of the weights by putting a little uscless weight into tho bottom, and so giring us a ship which with a rery steady gum platform has jet concealed in her the fearful danger that no ono can erer know when he rrould meet such a ware or wind as would send it to the bottom, and no porrer on earth and no seamanship on carth could prerent tho result. So much is that tho case that sailors are forced into adrocating the reduction of their sails simply in the fecling that there is no safety in haring masts-that jou cannot do it. This is a point on which I think the wise, scientific architect rasy rery well step in, and with his comrades reason out the whole state of things. Te sailors will be all ready to aid them with crergthing wo can learn at sea, to obcy their directions and study what they tell us we ought to study, and I hopo the combined hnowledge so ob. tained may bring about a more farourable state of things. MIr. Scott Kussell's paper is one of those mhich lead a great many to think on tho subject, and those who are led to think, will no doubt sooner or later take action.

Admiral RrDER : I slould like to make a small contribution to this discussion. When $I$ was employed as a naval attache in France, I learned that in erery cruising flog ship, there is a member of the Constructive Department of the French Tavy, lcarning from actually sccing at sea low ships bohare, his practical lesson of how to design ships. Why that is not done in our ecrice, I hare nerer been able to understand. I am perfectly confident of two things; that the joung constructor rould relcome most leartily the opportunity of going to sea, and $I$ ain perfeetly confident the oflicers on board would welcome him most heartily there. As far as I know, horrerer, at present there is no s5stem by means of which the joung constructor can attain any practical bnowledge of our ships" behaviour at sca. After the loss of tho "Captain," I asked one of the prominent members of the Constructive Department whether when they ascertained by testing that ship that her mazimum anglo of stability was of such an amount, that did not strike him as being rery small, as it did all naval officers. IIis reply was rery simple: "I did not attach "jmportance to it; I hare nerer been to sea; I havo nerer been on a cruize in a "ship." There is a rery great moral in that remark, and I very much wish that I had any influence with the $\Delta$ dmiralty which could induce them to take up the question, cending, as the French do, our Joung constructors to sea, making their promotion and adrancement depend upon their laving been to sea, and so learned their profession.

Admiral Frsmpoonxe: I mag state that that plnz was earried out in the School of Naral Architecture established at Portsmouth. The plan had the double effect of teaching the officers on board the mathematical side of tho question, and cnabling the constructors to learn somewhat of the seafaring side of the question.

Colonel Carter: Although I am a land-lubber, I take a great interest in this question. Our lecturer has giren us to understand that he has a great deal more information to gire us, and as this subject is so rery important, and ought rot to be luxriedly closed, I think it would bo a great benefit to the serrico if, on some future occasion, he will continue his lecture upon this subject. There are some questions I should like to put myself, but $I$ do not feel justified in doing so at this late hour of the erening; I will therefore respectfully suggest that MIr. Scott Russell should be asked to continue his lecture on a subsequent occasion.

Admiral Fismboorse: I am sure the Council will bo glad to fall in with that suggestion, particularly if Mr. Scott Russell would completo his eubject.

The Cramerax: Before asking Mr. Scott Russell to reply to the questions put to him to-night, or to inform us when he will farour us with the completion of his paper - for wo must all feel that it is a subject that may well be enlarged upon-I should like to offer a fer remarks on the paper, and on some obserrations that have been mado regarding it. I think, with reference to a remark by Admiral Selnrn, we are all opposed to useless ballast, ond wo may hope that all occasion for it has passed away. It has been, I will not say a custom, but an sceident of the past in connection with ironclads, and I do not think you will find anjone conaceted with the slip-building departmant of the Admiralty who mould adrocato patting useless ballast into a ship. I must also 
remark that it certainly is not the opinion of naral officers in general that our slips as now. built are of such a dangerous form, or weighted in such a dangerous manner, that we should hare any fear of going to sea in them in any circumstanees whaterer. My own opinion of them is, that our ironclads of the present day are, looking to all the scrrices that may be required of them, the finest ships in the world. Allmiral Selwyn asked whether it is not possible to build a ship that will right itself when she gocs on lee beam cnds. Jany of our ships will do so; I think Mr. White will perhaps bear me out in saying that some of them will go out to more than $100^{\circ}$, and right themselres. I do not inean ironclads, but troopships and others. Itany of then would do so if you could insure that their upper morks and lintelways wero ratertight. Our armour-clads and turret-ships would not go orer so far with safoty but thor haro such great stability that no sail that they carry, rronld crer bring them orer on their beam ends. If we did not feel safe on that point I do not think any of us would care to go to sea, but I am eatisfied I am speaking the opinion of a rery large majority of naral omeers, when I say that they hase no hesitation or doubt in placing confdence in the sca-going qualities, and sea-worthiness of our ironciad ships.

I cannot sit down without expressing my admiration of the clear and lucid manner in which Mr. Scott Russell has explained lo us the mystery - ware motion. I do not mean that ho has brought forward any new theory, but his exposition has been so clear, that I think anjone who lins heard it to-night will remember it as long as he lires. I should like rery much to hare the period and length of the "standard ware" clearly established, but it is a diffeult matter to obserre with accuracs, and no one has giren the matter more study or conducted more experiments on the subject than Mr. Seott Russell. If officers in the Nary knew what careful instructions ure issued by the Admiralty for obserrations on the length, periods, and height of mares, and on the rolling of ships, and also the admirnble was in which it is explained how these obserrations aro to be conducted, I think our naral arehitects would be orerwhelned with information on tho subject, instead of getting it, as they do now, rery rarely indeed. -With reference to the remark of 1 dmiral $\mathrm{R}$ yder-I clearly understood that when the naral architects were established at Greenmich, it was quito settled that those young men mere to go to sea to complete their training after they had passed their examination, and $I$ do think Admiral Ryder's suggestion ought to be most seriously considered, as it is one of great practical ralue.

Mr. Wmire : Erery student of naral architecturo who enters the College is under an obligation to go to sca should the Admiralty decide to send him, but no orders on that sabject hare as yet been issued.

Mr. Scorr RosseLt: I think I can answer at once the point which Mrr. White put, namely, that I had not marked the change of metacentre. I knew that Mr. White would know in a moment when I put these points there (pointing) that in the act of doing so, the metncentric height was raised a proportional quontity. And if I had wanted to put the thing technically in shape, as betreen him and myself, I should have said, "Iret us shift this metacentric height, and let us elift the centre of ballast "down the corresponding and equiralent quantity, and then we shall by those two " means get the two elements of stability, and we shall get them exactly as equira. "Icats of one another, and we shall get exactly the balnnee I am asking for."

With regard to ships of war, I nm obliged to say that the distribution of the meights of boilers and cogines that I hare sometimes seen, has been entirely contrary to the principlo mentioned, of bringing them as ncar as possible to tho centre of grarity of the ship, and as near as possible to the place where they would act as eflicient ballast, and at the samo time as weights in the place where they would produce least oscillation. I rill not, howerer, criticiso other people's ressels, because it is not my daty, and I dislike it. I mercly mean to say if I had not seen ressels in which all the great weights wero utterly erroncously distributed with a riew to these points, I should not have thought the obserration worth making. I will just give one example. I do not like to mention it because it is a ship of ny own building, but I remember having tho question to settle, whether $I$ would spread the boilers of a ship out in this manner at a certain distance, or whether I mould put two boilers into one, and place them in the centre further down. I took the boilers out of the wings, and pat them in the centre and put two boilers back to baek; I thus got a good and low disposition of the weights, and made an excellent ressel rithout 
any ballast. The engines and the ecrew ought to be regarded by the builder as weights, the disposition of which are entirely at the discretion of the designer, and $I$ tell you why: there is no reason in the world why the shaft of a screw propeller ghould not have any angle jou find it convenient to giro it, and therefore $I$ say to jon in the most decided manner that all tho bad dispositions I hare scen of screw engines hare been made through utter want of judgment and knowledge. You cau put your engines wherever you please, which you could not do till wo got the serew. propeller.

With regard to mares I hare giren you cxperiments occupring a large portion of ten years. My stardard ware is based upon hundreds of perfectly exact experiments repeated orer and orer again, and thoso experiments which mere mado betireen 183.1 and 181t hare not, so far as I hnow, ever been contradicted. I hare not in this lecture touched on the subject of the manner in which wares interfere with and modify each other, which makes tho obserration a matter of extremo difficulty; I beg to 525 , howerer, that I shall search the rolumes in which I can find any accurate waro experiments, and at oux next meeting I shall bo most lappy to give you a summary of the results of theso experimerts, and I only hope that they will do what I want, give me my 3.14159 instcad of the 3.57 which $I$ am forced to adopt by nature berself pressing it on me.

With regarl to what Admiral selwyn said in regard to the inclinations of a ship, there are forms of ships rhiels no possiblo derangement conld ever turn upside-domn; but at the same time I admit frankly that there are ships so constructed that if they were turned upside-down, they would hare much greater stability than when they arc downside-up, and those aro dangerous ships, and ought to bo aroided.

Tho Mlecting was then adjourned to Monday, the 9th of June.

\section{Monday, June 9, 1879.}

Colonel Canter: It is with some diffdence that I address an audience upon this subject, but if I hare made an error of judgment, I hope jou will excuse it. Mr. Scott Russcll haring cridently from want of time hurried his last lecture to a conclusion, I ventured to suggest from the extreme importance of tho subject, which the sad fate of the turret slip the "Captain," had so indelibly impressed on crery mind, that he should be invited to address us again. That suggestion was furourably entertained both by the audience and the lecturer, and we hare now been faroured with MIr. Scott Russell's further obserrations, which wo must all allow wero particularly lucid and clear on that portion of the subject which is both difficult and complicated to discuss. I could not tell, of course, how he would further unfold and explain his subject, so it is consequent upon what I heard at tho first lecture and the discussion which followed that I make the following observations. Mr. Scott Russell just had time to draw for us the sectional form ho thought best for a stable ship, namely a circlo with a pair of shoulders ndded, which, by adding width, gives stiffiness, and showed us the place where ballast should permanently be, namely, at the bottom, but inside the eircle, which gires stability. Mr. Scott Ruszell's idea, so lueidly conreyed, set me thinking, and the problem which had to bo solred is what Admiral Selwyn rery appropriately mentioned, namely, how can stability be given to ehips which are so hearily weighted with maseire iron turrets and moneter guns on deck, and thick iron sides above watermart? The position that all these things of necessity occupy, renders a ship top beary, and thereforo easily capsized if it is not scientifically counterueted. Without such counteraction it would not require the furious raging of storm ocenn wares to effect tho capeizo; but when a ship has to contend with the violence of fierce winds and rushing mountain rares it should posgess all the means arailable for maling her imposaible to turn orer. Now have our ships erery arnilable means to sccure this end $P$ I answer No, and in my opinion very far from it. When I first examined the beautiful model of tho "Captain" which is in this Inotitution, I was no longer surprieed that that vesel turned over. 
II surprise was that she remained so long as she did upon the surface of the sca. And why do I state this? Because-I am afraid I am now going a little at variance with the theory MIr. Scott-Russell has put forward-because sho was circular in form below, which offers no resistance whaterer to the power of tho wind and the rave; she had no keel, which does. I feel conrinced that a kecl to an iron turreted ship is essential to its safety, and to all ships, I should say, necessary to effect moderation and a lessening in rolling. When a ship with a keel rolls, tho displacement of a large body of leary water which a becl necessitates, rould cause the rolling motion of the ship to be gentle and slow, whereby time would be obtained for the monntain maro to pass, and so the ship rould roll back again on the oppositc side of the ware beforo she could lurch over to a dangerous angle. To width of beam therefore, which tends, as Mr. Scott Russell has explained, to storm stability, I would also add, as an essential to the ship's anfety, a kcel. With such monstrously weighted decks as our men-of-rrar now hare, I should not onls hare a kecl, but a kcel of a particular construction, that is to say, if such construction should not be found in practico different to what I conccire it probably would be. $\mathrm{Mr}$ theory is that the form of the keel should be such as to make the ship slow in rolling, and this adrantage could be secured by making the keel gradually broader towards its basc, but tapering towards the rudder as also tho stem, so as not to interfere with the proper action of the water on the rudder or retard the ship's onward progress. As the ship rolls, the keel by this form would retard and lessen the momentum of the roll, and so rould cause the ship to roll slowly and gently and not riolently, which a high conical ware combined with a sudden gust of wind would effect, and with a dangerous momentum, without a keel. There would be an objection to this form if in practice it interferes with the buoyancy of the ship. I do not adrocate, howerer, that the form should be carried to ang excess, especially in a very deep keel. If the water below rises equally or nearly so with the water on the surfice, the form would not interfere with the buojancy of the ship; but if otherwise, I think that it would, but probsbly only slightly, cren if the heel were a rery decp one. A keel which brondens at its baso may requiro practice to confirm its use, but a keel with perpendicular sides and heavily weighted, I beliere to bo absolutely essential to safety when ships aro weighted on their decks with iron turrets and large guns. Mr. Scott Russell has condemned the "bilge" keels, but I fail to see that they are not a valuable addition to ensure slow rolling. They would, $I$ suppose, cause the ship not to answer ber helm so quickly as when without them, but this, if it bo the case, is a consideration that is of comparative insignificance to stability, for stability is a quality that our men-of-war must possess orer and abore erery other. I contend that a hearily weighted keel would form the best possible bailast, and would not usurp the room arailable for storage. I rould illustrate this porrer of securing the greatest stability by bringing to your notice the principle of the steel bar. A stcel bar has a long arm and a short arm. I place a weight $A$ at the end of the ehort arm, and another weight nearly equidistant from the point of suspension $C$, which I call $B$, on the long side of the bar. Those reights, we will suppose, balance each other, but when I remore $B$ further towards the extremity of the long arm to D, B will fall, say to the bottom, and A will correspondingly rise, that is to the top, immediately over $\mathbb{B}$. This is exactly what we want our ships to do. Iret $A$ now, in its rertical position, represent our turrets and guns, $\mathbf{B}$ the heel of the ship, then the further we can hare our heary keel to counterbalance the turrets and guns on deck (which should be, as we can now see, as Iow 23 possible) the moro effectual is such weight, so that when a ship rolls, which it always must, more or less, when it rides longitudinally orer crescent wares, its natural position being at right angles to the surface of the water, $B$, the weighted keel would, by the law of graritation, always be forcing the ship to assume a rertical position. A keel, therefore, such as I have indieated, rould form the most effectual ballast, and would secure the greatest stability to the ship.

Admiral RYDER: I should lihe to ask one or two qucstions. Mr. Scott Russcll has giren us the Jength of the ware, the height of the wave, and the period of the ware; but do his researches enable him to gire us the angle of the slope of the ware? When we were on the Committee of Designs some years ago, me Eought that information, and wero told by tho scientific gentleman who adrised us that tho slopo 
of an ordinary soe wave nerer exceeded 4 deg., I noticed ono of the great wares of translation which he speaks of, at Hakodadi, in Japan. There, orerybody was full of an extraordinary wave that had reached them, though they did not know from whenec, or anything about it; nor had any liring man in his recollection secn a similar ware. It rose eight fect, and they congratulated themselres that it came at low water, instead of at high water spring tides, in which case it would certainly hare drowned half the inhabitants. As it was, the top of the ware was only about two or three feet higher than tho highest spring, and though it flooded their cellars, I do not beliere anybody was drowned. They said there must have been an earthquake on the other side of the Pacifie, and so it turned out. I suppose these wares that lave their speed due to the depths, when thor pass orer different depths rary, and acquire a kind of mean speed.

Mr. Scotr Ressell: Always; they go slower and faster.

Admiral SeIwTr: I wish to ask AIr. Scott Russell to be good cnough to tell us one or two things; and one is whether ho has remarked at sen that on the calming down of the licary sea arising from a gale of wind, the smaller mares gradually mergo themselres into larger rares of longer period. Secondly, I would ask whether he considers it absolutely necessary that tho bottom should shallow in order to produco the ground swell. I hare been a good deal interested in the subject, and am specially intercsted in what MIr. Scott Russell has said to-night, because, although he garo us the fear 1831 as one of the first instances, I have been making researches lately, and I am rery mueh disposed to say that the first record we hare of a big ware was in Noah's time, and that there were five deluges recurring after that. In the year 1822, not to go to other instances, the uphearal of the Chilian const to the extent of eight feet, sent a ware of that.claracter across to $\mathrm{New} Z$ caland, and in the submergence of Calla something of the same sort took place. In short, the more we look into the question of such grent wares, of such rapid transmission, tho more we see that they aro principally caused by serious disturbance at the bottom of the ocean. At St. Helen there is a rery curious form of warc, which cones in periodicalls, and in a mensure at $A$ secnsion also. It is a series of big wares coming in for a day, setting in with anful fury, often in a perfect calm, without any sufficient eause whaterer that we ean see, and they are perfectly local. They generally set in from the eastward; we de not hear of any great disturbance having occurred, but these rollers set in at periodical times with derastating fury very much of tho character of the ground swell of which Mr. Scott Russell has been speaking. I think the peper, both on tho former occasion and on this, has very much adranced our mode of thinhing of wares in general, and will lead to more close obserration among the officers of the Serrice, as to the formation and courses of wares. As to myself, I am afraid I must still hold to a Eort of affection which belonged to my youth with regard to the trochoidal ware in which the friction of the deseending particles plays the greatest part in causing tho breaker in sea mares. I dare eay Mir. Scott Russell, in speaking of the circular morement of an atom of water, will allow that there is always a translation of that atom forwards in erery case, combining the circular with the forward morement. . With regard to the question of storm stability as distinguished from smoothwater stiffness, MIr. Seott Russell has done a great deal to show us what in his opinion would be the best form of ressel to combat what we all regret, the absenee of real stability, although there is a great stiffness of platform in the modern contrivanecs which they call ships. But I am not satisfied with any of the modes which hare jet been proposed for doing away with tho diffeulty. I see that wo are still bound to heary weights abore and light bottoms in order to carry these heary weights, and as, apparently, the heary weights must bo carricd high up, I do not see how by any other centrivance than increasing tho weights below, we can balanco the roights abore; but in doing so, unfortunately for ourselres, we incur the reproach of carrying more weight than we hare any uso for, and although jachtsmen show an enormous raluo for what they are pleased to term tho "precious metal" in their kecls, Jet I doubt whether, added to the weights we are obliged to carry, a naral architect would liko to be told to carry counterbalancing weights for no other purpose than that of counterbalancing the armour and the guns. Is there any other mode of getting rid of this difficulty? If wo are to carry these weights rery high up, what ailrantage does it gire us, and why should we continue to do it? It is quite possible tlie Russions 
may be right, and that the time for ironelads is gone, and that there are no more ironclads to be built. Iut tho world does not think so at present, and I an disposed to think the failure of funds has moro probably led to that conclusion than any other neccssity. Howerer that may be, it is quite clear as long as wo hare heary guns and armour, we hare to provide for heary weights on board a floating structure. If wo still insist on getting our speed in the looting structure by modern slopes of ten beams to a length, it appears impossible to get rid of tho disadrantages of unstablo cquilibrium. I do not sce any Tray out of it in that direction. If Mr. Scott Russell can give us any idea how we can get storm stability combined with smooth-water stiffness, I am suro wo shall bo happy to hear it, and I am quite sure if he does not know it he will very candidly say so, and tell us that on our present line there is no chance for our doing much in that direction. IT will also, I hare no doubt, at somo futuro time, be ready to tell us something about how wo can do it, and I lope that time will soon arrive.

Captain Burgess : I do not know, Jrr. Scott Russell, whether you crer saw a form of ressel introduced by MIr. Forell, in which all the sections tomards bor and stern mere semi-circular. He had some resscls built for the 3Iediterrancan trade, and he obtained somo excellent results; but I do not think that tho plan was erer generally introduced.

IIR. SCOTt ReSSELI : One of my first resscls was built in that way.

The Cuamuas : I hare myself observed sereral instanees of maves sueh as Mr. Seott Rusicll described. I mas once lying on the coast of Africa in perfectly smooth water with not a breath of air; tho glass went down rery much, so much that $I$ felt it necessars to get steam up. I walked up and domn for hours watching to see what was coming, as the glass continued to go down. Finally I saw a white lino on the horizon. This wasia solitary ware rolling in about sir fect high aboro the natural level without a hollow in front. My bow was to tho ware, I therefore had nothing to do except to stcam ahead to keep tho strain of the cable. It camo along with great relocity. A schooner lay close to us brosdside on. IIer crew anw the ware coming, they lashed ererything on deck, and then got in the rigging. It nearly capsized her; sho made a dash at us, took away my quarter boat and stern boat, carrying away her bowsprit and fore topmast. There was only one ware that passed and broke on the beach. I felt sure that a storm had passed outside, and on examining some ships' iogs, found that tro ressels had been in a circular storm, and one was dismasted. In another case I sar an illustration of the transmutation of small rraves after a storm into a ground swell. I was lying at anchor in Table Bay in three fathoms, with 75 fathoms of chain out, in perfectly calm weather; ono of these solitary wares came in and took tho ressel at such a rate astern as to cause a tremendous jork as if it was tearing the bits out. I jumped up to eco what was tho matter but could eco nothing. We went forward and the cable ecemed to bo all right. Concluding that something must haro occursed, after supper mo hove up and found the anchor shackle had broken. This is why Table Bay is so dangerous to reesels. This class of solitary ware comes and takes a ressel, brings her chain quite straight, and it breaks with the jerk. In another case in (Mina, preceding a cyclone, tho whole River Yang-tse-Kiang was unusually red, from the earth being stirred up by the coming storm, quite 48 hours before it arrived. I afterrards traced that cyclono to bo 1,000 miles in diameter and to have been 2,000 miles axry from us when this disturbance" of the water and ground ewcll came up the Yang-tse-King. Captain Maury's cousin, and other rery accurate observers, were in this cyclone; I got their logs and mapped out its course. Mr. Scott Russeli has giren us a truo explanation, and it is most important to recogniso the distinction betreen the first and second order of wares ; to confound these is to loso all judgment in tho matter. To build ships with referenco to one is to hare them failing in the other; and to assume that becauso ships hare been eafo for a number of years in one class of ware, they will thereforo be perfectly safo in another, is extremely unscientific and dangerous. There was some conflict on the last occasion between Mr. White's standard and Mr. Scott Rusecll's. The question is whether there has not been a confusion of wares as well as of their standards, whether thero is not a stanciurd for smooth-water wares and an entirely different standard for storm nares? 
Admiral SeLtry: At St. Helena no ship dares to remain at anchor when one of these rollers comes in; if she dues, her chains will not hold her, and such a ware with such a relocits of translation meting a slip which has little initial stability either on quarter, bow or brondside, would bo a most dangerons one for her.

3Ir. Scotr RUSSEI- in reply: Admiral Ryder asks me with regard to tho slopo of the ware. The slope of this ware is an extremely gentlo one, but the trochoidal form absolutely remains. The trochoidal form is the result of the combination of the cireular motion with the rectilincar motion. The propagation of the ware takes placo equal distonees in equal times, and the ware being propagated cqual distances and in equal times, it is the circular motion that alters the slope of the ware. First of all, the slope of the ware is extremely gentle. I cannot say how small the anglo is until it becomes a storm mare, and then the anglo certainly gets up to $60^{\circ}$. The atorm ware is a sudden eleration of the ware up to double its former height; that altrays takes place both in the ground smell and in the other. A remarkable thing in the ground strell is this. If you sce the ground swell regularly breaking with the rares 20 feet high, you may bo quite sure that the water there is a little more than 20 feet deep, and always mben this ground swell comes to a height equal to its depth it assumes a position of tottcring equilibrium before it gets to the maximum, so that tho depth will always be greater than the water appears to bo when judged by tho height at the top. In like manuer with regard to the breaking of the surface ware, apart from all rule of course, the wind will piteh it orer and.break it, but if rou can imagine a surface waro breaking merels b5 its own gentle curre fou will find the storm ware breaks whenerer its heiglit becomes equal to abont onc-fourth of its length. I hare nerer scen ono of them able to riso to a greater height than that. The sharpest ware $I$ hare erer ecen on the surface of the water is a ware of which the height is one-fourth of the length. In regard to the ground stsell and the ware of translation the length is rery great, but at the same tirne I hare secn them culminating in a smaller height in tho act of breaking to that of the ordinary surface storm ware. With regard to Admiral Selwyn's question, I may say I think tho ground swell would break by mere accumulation. Supposing an island to rise rery slowls, the result will bo a rery long low wave, and whenerer this waro comes into a good deal shallower water tho shortening of the ware must increase the height and therefore the long earthquake ware may, by sudden shortening, become a breaker. Tides become breakers; when they come up a shallow riter they become bores; although they are rery long, still the crest becomes a brenker from, as I think, this slortening of the ware. Supposing a storm to hare existed with the surfnce wares, then the surface wares as long as they continue storm wares, will break, and supposing a second ware of much smaller size goes orer the surface mare, it breaks, and therefore I say a great continuation of storm surface mares would break on the top of cach other, whenerex their crests coineide, and would gradually in that ray settlo down and be used up.

With regard to the rery diffeult problem which the 1 dmiral has put to me as to carrying weights high up, without carrying uscless weights low down, there is only one solution, and that I think I mentioned formerly. It is to begin with the resolution that we will not carry any uscless weights at any cost. Then put as much weight as you think desirable for strength into the bottom of your ship, and so design your cngine and boilers that all arailable and useful weights shall bo plaeed at such a depth as to assist in giring the stability that you want. It really comes to this, that you will keep thoso top weights of yours as low down as you cau, and you really come back to the conclusion that heary armour high up is unwise, inexpedient, and inakes an unseawortly ship. I adrocite keeping the armour low down, not putting tall turrets up into the air, but amning a ship of war with a particular hind of gun kept low down as near the water line as conrenient, and in that way making her a good scaworthy ship. I remain of opinion that you ought to consider a ship of war as haring this essential point in her, that first sho must be a seaworthy slip; and haring done that, I think jou can make her a perfectly ecaworthy ship at the same time that jou gire her all the protection she wants. What is practico in life but this? Tako tho ineritable conditions and make the best of them you can. Therefore when a problem of building a ship is giren you, and you hare giren ber the right size and shape, and put your weights and jour boilers in the right place, and 
hare kept your guns and armour as low down as you can, fou hare dono all that is possible.

With regard to the question of keel, I rould simply say this,-that very often we hare no choice. When we build a yacht we are allowed to put the keel as low dom as we please, but when wo come to build a ship of mar, we dare not put an inch of kecl on, because of the draught of mater. But I will call attention to the fact that the bow of the ship is practically kecl and nothing clso; it is a sharp redge and prercents rolling. Fith regard to the oscillations of a ship, I would also call attention to this, that a glip has no tendency to oscillate. Nothing can cause it to do so, excepting either the wind abore, or the action of the sea upon its keels. Therefore it is that I do not like these bilge kcels, because they are just the thing which enables tho ware to compel the ship to oscillate. The only reason why we do not use keels is, that we must gire these cnormous ships a limited draught of rater. What we must do, is to build the ship of such a form, and put her weights in such a manner that she shall not of herself have any tendency to roll. That is why I begin with the circular form, and with that cireular form the ship does not roll. With regard to MIr. White's standard, I think the matter is very simple. In the former lecture I gare this series of wares, and in this scries there was a wave which I gare as the standard 3.57. 'That ware mis the result of 10 years' obserration, and you find hundreds of those wares in the reports of the British Association, all of them shoring this particular dimension as tho one standard. Until, therefore, another eet of experiments of equal ralue has been made, establishing some otler standard, I think ne must keep to that as the old standard. I think that what perhaps misled him ras, that he thought I was speaking of the deep-sea wares instead of the surface wares, and if he liad been here to.night, I could hare presented him with a standard ware, which would bo exactly the ware he wanted. There was a ware of 5.67 in this elass, and the ware of 3.57 remains to please me in the other class.

Admiral RxDER: Hare tho experiments been as extensire for that waro as for the other?

MIr. Scotr Resselu : As extensite, and on a much larger scale. The first considerable report was in 1837, and tho remainder of the reports were made in 1811.

- The Cnanaray : I am suro you will allow me to return jour thanks to Mr. Scott Russell for his rery interesting paper.

NAMIES OF MEMEBERS who joined the Institution between the Ist July and the 30th September, 1879.

LIFE MIEXIBERS.

\author{
Arbuthnot, William, Lieut.-Colonel 14th . WJndham, C. J., Captain 83rd Regt. \\ IIussars. \\ MreCallum, Ir. E., Iieut. R.E.
}

Tyler, Henry E., Lieut. R.E.

Dunlop, H. D., Captain R.A.

Brucc, E. A., Major Madras Staff Corps.

Jones, G. Turper, Licut. R.E.

\title{
ANNOAT SUTSCRIBERS.
}

Markham, Clements.R., C.B., F.R.S., Undermoad, Walter O., Captain 4th late R.N.

Paget, A. do B. V., Lieut: 63th Regt.

Farren, R. T., C.B., Lieut.-General, Colonel 35th Regiment.

Carter, F. TV., Najor Duke of Edinburgh's Artillery Mrilitia.

Stokes, Sir John, K.C.B., Colonel R.E.

Fordsce, Alex. D., Captain Duko of Edinburgh's Artillery Mrilitia. Hussars.

Dick, J. P., Licut. Duke of Edinburgh's Artillery IIilitia.

Woolcombc, II. B., Captain R.N.

Whelan, F. A., Licut. R.3r.I.I.

Carden, Henry C., Licut. 11th Regiment.

Thompson, Ross, Lieut. 11th Regiment.

Farde-Buller, Hon. Walter, Lieut. 11th

Regiment. 